\title{
A new species of long-necked turtle (Pleurodira: Chelidae: Chelodina) from the late Miocene Alcoota Local Fauna, Northern Territory, Australia
}

The new species Chelodina (Chelodina) murrayi is described from the late Miocene Alcoota Local Fauna of central Australia, in the Northern Territory. The new species is based on shell fragments and can be diagnosed by a ventrally reflexed anterior margin of the plastron, a ventrally narrowed cervical scute and strongly dorsally curved margins of the carapace extending from approximately peripheral two to peripheral nine or ten as well as by a unique combination of characters. Within Chelodina the new species is part of the nominal subgenus and within that subgenus it is most closely related to the Chelodina (Chelodina) novaeguineae species group. This is not only the oldest record but also the most southerly occurrence of this species group. 
1 Adam M. Yates

2 Museums and Art Galleries of the Northern Territory

3 Museum of Central Australia, P.O. Box 831, Alice Springs, Northern Territory, 0871

4 Australia

5 Corresponding author: Adam M. Yates, Museum of Central Australia, P.O. Box 831, Alice 6 Springs, Northern Territory, 0871, Australia, ph. +61 (08) 89511148, email:

7 adamm.yates@.nt.gov.au 


\section{Introduction}

9 Chelodina is an extant genus of chelid turtle found in Australia, New Guinea, East Timor and

10 Roti Island, Indonesia (Georges \& Thomson, 2010). Popularly known as long-necked or snakenecked turtles they are readily distinguished from other Australasian chelids by their elongated necks, four-clawed forelimbs and contacting gular scutes on the plastron (Cogger, 1975; Georges $\&$ Thomson, 2010). The genus is also distinguished by a distinctive skull morphology including the loss of the temporal bar, fusion of the frontals, nasals separated by an anterior process of the frontals and an extensive quadrate-basisphenoid contact (Gaffney, 1977). Gaffney (1977) proposed that the genus shares closer relationships with long-necked South American chelids (such as Hydromedusa and Chelus) than with short-necked Australasian chelids on the basis of shared derived morphological features. However phylogenetic analyses of nuclear and mitochondrial genes indicate that reciprocal monophyly of South American and Australasian chelids is a much more likely scenario (Seddon et al., 1997; Georges et al, 1998). In keeping with its probable monophyly, Georges et al. (1998) unwittingly resurrected the old name Chelodininae Baur, 1893 for the Australasian clade when they proposed the same name as new. Within Chelodininae, Chelodina is invariably the sister taxon of all other Australasian chelids in all analyses where Chelodininae is recovered, or the taxon sampling is restricted to chelodinines (Georges \& Adams, 1992; Seddon et al., 1997; Georges et al., 1998; Thomson \& Georges, 2009).

Within Chelodina three separate species groups can be recognised on the basis of morphology and electrophoretic analysis of allozymes (Burbidge, Kirsch \& Main, 1974; Georges, Adams \& McCord, 2002). These groups have been assigned separate generic names (Wells \& Wellington, 1985; McCord \& Ouni, 2007) but a recent synthetic work on Australian turtle taxonomy has treated them as subgenera (Georges $\&$ Thomson, 2010) and this practice is followed here. $C$. (Chelodina) includes smaller species with broad plastron and a slender head and neck with a length that does not exceed that of the carapace (Georges \& Thomson, 2010). $C$. (Macrochelodina) includes larger species with a long broad head and neck that exceeds the length of the carapace and a narrow plastron. $C$. (Macrodiremys) includes a single species, $C$. (Macrodiremys) colliei, which is outwardly similar to $C$. (Macrochelodina) but has some unusual characters such as a continuous row of exposed neural bones in the carapace and a lack of posterior expansion of the carapace (Burbidge, Kirsch \& Main, 1974; Georges \& Thomson, 2010). Furthermore molecular phylogenetics has consistently found $C$. (Macrodiremys) colliei to be more closely related to $C$. (Chelodina) than to $C$. (Macrochelodina), supporting its separation from the latter (Seddon et al. 1997, Georges et al. 1998; Georges, Adams \& McCord, 2002).

\section{The fossil record of Chelodina}


42 Chelodina has a long fossil record, as one might expect from such a deep branch within

43 Chelodininae. However it is much sparser than the fossil record of the short-necked chelodinine

44 clade.

45 The earliest specimens referred to Chelodina have been found in the Eocene deposits of Redbank 46 Plains in south eastern Queensland. Here there are three forms known from incomplete shells, 47 one of which has been named C. alanrixi (Lapparent de Broin \& Molnar, 2001). None of these 48 forms can be easily assigned to the extant subgenera, not least because the material is limited and 49 incomplete. In the case of $C$. alanrixi there are some similarities with $C$. (Macrochelodina) but 50 there are also some notable plesiomorphies such as a complete row of exposed neural bones in 51 the carapace and a posterior vertebral scute that is as wide as the suprapygal scute (Lapparent de 52 Broin \& Molnar, 2001). These indicate that C. alanrixi could well belong to the Chelodina stem53 group, rather than to any of the recognised subgenera but this will need to be tested with more 54 complete fossils and a phylogenetic analysis of Chelodina ingroup relationships that includes 55 fossils. There is a considerable gap between the Eocene and the next oldest occurrences of Chelodina in the early to middle Miocene carbonate deposits of Riversleigh in Queensland and Bullock Creek 58 in the Northern Territory. Chelodina has been recorded from two sites at Riversleigh, Gag Site and Quentin's Quarry, both of which have been assigned to system C (Archer et al., 1989). However, constrained seriation analysis indicates that Quentin's Quarry is referrable to the early Miocene Wipajirian Australian Land Mammal Age, whereas Gag Site belongs to the younger middle Miocene Camfieldian ALMA (Megirian et al., 2010). The Quentin's Quarry specimen is an intriguing skull fragment that exhibits several distinct autapomorphies and cannot be easily placed in any of the extant subgenera (White, 1997). The specimen from Gag site is a fragmentary shell that would appear to have affinities $C$. (Macrochelodina) based on the absence of exposed neural bones and the length of its intergular scute which is only slightly longer than the midline contact of the pectoral scutes (Gaffney, Archer \& White, 1989).

The Camfield beds of Bullock Creek are Camfieldian in age and have produced two distinct Chelodina species. Both species are only known with certainty from isolated epiplastra (Megirian \& Murray, 1999). One of these, Chelodina sp. B, may belong to C. (Chelodina) based on the squared-off profile of the anterior lobe of the plastron.

72 The record becomes a little better in the Plio-Pleistocene. From Tara Creek in Queensland there is 73 a Chelodina specimen that is likely to be similar in age to the nearby Bluff Downs local fauna 74 (Gaffney, 1981). The Bluff Downs local fauna is Early Pliocene in age and belongs to the 75 Tirarian ALMA (Megirian et al., 2010). The specimen is unusual in that it lacks a finely 76 ornamented surface even though the seams between scutes are well-marked (Gaffney, 1981).

77 Based on the narrow anterior lobe of the plastron, a long inter-pectoral seam which exceeds the 78 length of the intergular scute (Gaffney, 1981, fig. 8), this specimen would appear to be a member 79 of Chelodina (Macrochelodina). 
80

81

82

83

84

85

86

87

88

89

90

91

92

93

94

95

96

97

98

99

100

101

102

103

104

105

106

107

108

109

110

111

112

113

114

115

116

117

From the Pliocene Bluff downs local fauna itself there is a single nuchal bone that has been identified as Chelodina based largely on the presence of a broad, square-shaped cervical scute (Thomson \& Mackness, 1999). The specimen was tentatively assigned to the nominate subgenus (as the 'Chelodina longicollis group') on the basis of its well developed ornamentation. However, as the authors themselves note, this is a variable character, for example Chelodina (Macrochelodina) insculpta also has well-developed surficial ornamentation (Thomson, 2000, fig. 4).

Chelodina (Macrochelodina) insculpta is a named fossil species based on fragments from the Plio-Pleistocene of the Darling Downs that bear a close resemblance to C. (M.) expansa but differ from it in a having a less flared margin of the carapace (Thomson, 2000).

Lapparent de Broin \& Molnar (2001) point out that a posterior plastral fragment figured by Gaffney (1981, fig. 18a) belongs to Chelodina based on the rounded shape of the posterolateral margin of the ischiadic scar on the dorsal surface of the xiphiplastron and the rounded nature of the fine tubercles that decorate its ventral surface. This fragment comes from the late Pleistocene, or Naracourtean, Katapiri Formation of Lake Kanunka, in the Tirari Desert of central South Australia. A second probable Pleistocene from central South Australia is represented by an isolated cervical vertebra from Cooper Creek (Gaffney, 1981). Unfortunately neither specimen displays diagnostic characters that would allow determination of their subgeneric affinities. Nonetheless these specimens are interesting because they show that Chelodina was surviving in central Australia until quite recently, well outside its present range.

Lastly there is a Naracourtean (late Pleistocene) record of Chelodina from Henshkes Cave, in south eastern South Australia based on isolated plastron elements (Gaffney, 1981). These are similar to the extant C. (Macrochelodina) expansa (Gaffney, 1981).

While it is highly likely that remains of the widespread, common species C. (Chelodina) longicollis are present in some of many Naracourtean vertebrate faunas of south eastern Australia, none have been positively recorded.

Thus $C$. (Chelodina) has an exceptionally poor fossil record, if any at all, with just a couple of fragmentary possible occurrences reported in the literature. Here I describe a new species of this subgenus from the late Miocene vertebrate fossil locality of Alcoota Station, Northern Territory. This is the first definite occurrence of the subgenus in the fossil record and the first diagnosable extinct species in the subgenus.

The electronic version of this article in Portable Document Format (PDF) will represent a published work according to the International Commission on Zoological Nomenclature (ICZN). and hence the new names contained in the electronic version are effectively published under that Code from the electronic edition alone. This published work and the nomenclatural acts it contains have been registered in ZooBank, the online registration system for the ICZN. The ZooBank LSIDs (Life Science Identifiers) can be resolved and the associated information viewed through any standard web browser by appending the LSID to the prefix "http://zoobank.org/". 


\section{Geological Setting}

122 The Waite Formation is a late Neogene filling of the Waite Basin, a small intracratonic basin 123 located in the Northern Territory to the northeast of Alice Springs (Woodburne, 1967). It is a 124 coarsening-upward sequence of fluviatile silts and sands with minor limestone beds (Woodburne, 125 126

127 128

129

130

131

132

133

134

135

136

137

138

139

140

\section{Systematic palaeontology}

142 TESTUDINES Linnaeus, 1758

143 PLEURODIRA Cope, 1864

144 1967). Two vertebrate fossil-bearing horizons are known, one giving rise to the older Alcoota local fauna and the other the younger Ongeva local fauna (Woodburne, 1967; Megirian, Murray $\&$ Wells, 1996). The Alcoota Local Fauna is found in an extensive, dense, jumbled bone bed. The bone bed is thought to have formed from a debris flow that incorporated the skeletons of many hundreds of animals that had died in a drought-related mass mortality event around a major waterhole in an ancient river system (Murray \& Vickers-Rich, 2004). Almost all of the bones in the deposit are disarticulated and randomly scattered. The bulk of the fossils belong to terrestrial species, dominated by the small macropodine wallaby, Dorcopsoides, several diprotodontid marsupials and large dromornithid birds (Murray \& Megirian, 1992). Turtles are rare in this deposit and are only known from isolated bones of the shell. These fragments have received little attention in the scientific literature. They were first mentioned by Newsome \& Rochow (1964) and then again by Gaffney (1981). Neither were able to identify the limited material as anything more precise than 'Testudines indeterminate'. An intensive collecting program led by the Museum and Art Gallery of the Northern Territory over the past three decades has produced many more pieces of turtle shell, including diagnostic elements that allow a new species to be recognised.

\section{CHELIDAE Gray, 1831}

\section{CHELODININAE Baur, 1893}

Chelodina Fitzinger, 1826

Chelodina (Chelodina) (Fitzinger, 1826)

Chelodina (Chelodina) murrayi sp. nov. urn:lsid:zoobank.org:act:9DDFE14D-8E52-4F7D-B148-F552100865C9

Holotype. Museums and Art Galleries of the Northern Territory (hereafter, NTM) P5364, right epiplastron (Figure 1). 
152

153

154

155

156

157

158

159

160

161

162

163

164

165

166

167

168

169

170

171

172

173

174

175

176

177

178

179

180

181

182

183

184

185

186

187

188

189

190

Referred Specimens. NTM P5337, peripheral, probably left peripheral 2; NTM P5369, left hyoplastron; NTM P5370, nuchal; NTM 5371, left peripheral 8; NTM 5373, peripheral, probably left peripheral 10; NTM P5374, right xiphiplastron; NTM P5375, left hypoplastron; NTM P5376, mid-series costal; NTM P5377, proximal end of right costal 7; NTM P5378, indeterminate peripheral; NTM P5409, distal end of right costal 2; NTM P9810, left hypoplastron; NTM P9892, right hypoplastron; plus many other poorly informative shell fragments that are unregistered in the NTM palaeontology collection.

Locality and Horizon. All specimens come from the lower bone bed of the Waite Formation on Alcoota Scientific Reserve, 200 km northeast of Alice Springs, Northern Territory, Australia. The lower bone bed (Alcoota Local Fauna) is Late Miocene in age or Waitean in terms of Australian Land Mammal Ages (Megirian et al., 2010).

Etymology. In recognition of Peter Murray, who has led two decades of excavation at Alcoota and has published many significant contributions to our knowledge of the site.

Diagnosis. A species of $C$. (Chelodina) with the following autapomorphies: a sharp, ventrallycurved lip along the anterior margin of the gular scute of the plastron. Ventral side of the cervical scute of the carapace is $55 \%$ of the width of the dorsal side. Dorsally-curved lateral margins of the peripheral extending away from the bridge area both anteriorly and posteriorly, perhaps as far as peripheral 2 anteriorly and peripheral 10 posteriorly.

Differential Diagnosis. Apart from the diagnostic autapomorphies mentioned above C. (C.) murrayi has a unique combination of characters that allow it to be distinguished from all other Australasian chelids. It can be distinguished from all short-necked Australasian chelids by the presence of a midline contact between the gular scutes, anterior to the intergular scute on the plastron. It can be distinguished from Chelodina (Macrodiremys) colliei by the lateral expansion of the anterior lobe of the plastron, the location of the triple junction between the intergular, humeral and pectoral scutes on the epiplastron and a robust, medially extended anterior bridge strut of the hyoplastron. It can be distinguished from species of Chelodina (Macrochelodina) by the lateral expansion of the anterior lobe of the plastron, a broad, tear-drop shaped sutural surface on the anterior bridge strut, absence of a well-defined line on the anterior bridge strut demarcating the attachment of the dermis and the short junction of the pectoral scute pair that was exceeded in length by the intergular scute. Within Chelodina (Chelodina) it can be distinguished from $C$. (C.) longicollis and $C$. (C.) steindachneri by a large anterior bridge strut that almost certainly extended onto the pleural bones. The strongly dorsally curved margins of the peripheral bones distinguish it from $C$. (C.) steindachneri, C. (C.) pritchardi and $C$. (C.) reimanni which have no marginal curving. The well-developed and extensive nature of this curving also serves to distinguish the new species from $C$. (C.) novaeguineae and $C$. (C.) canni which only develop weak marginal curving in the bridge region. It can be distinguished from $C$. C. (C.) pritchardi, (C.) novaguineae, $C$. (C.) mccordi, and $C$. (C.) reimanni by the widening of the anterior plastral lobe anterior to the axial notch. The lack of a distinct lateral bulge of the femoral scute on the xiphiplastron distinguishes it from $C$. (C.) longicollis, $C$. (C.) novaeguineae and $C$. 
191 (C.) reimanni. Finally the failure of the intergular scute to extend broadly onto the hyoplastra

192 distinguishes this species from $C$. (C.) canni.

\section{Description}

\section{Carapace}

195 Nuchal bone. The nuchal bone (NTM P5370) is the most informative part of the carapace that has 196 been recovered from Alcoota (Fig. 2, Table 1). It is a roughly trapezoidal, bilaterally symmetrical 197 plate that is only marginally longer than it is wide at its posterior end. The lateral edges that 198 contacted the first peripherals on each side are gently concave whereas the posterior margin that 199 would have sutured with the first pair of costals is convex. The seams that mark the boundaries of 200 the scutes on the dorsal surface of the nuchal indicate that the anterior end was covered by a 201 central cervical scute which was flanked on each side by the first pair of marginal scutes. The 202 203 204 cervical scute is broadly rectangular and is 1.27 times longer than it is wide. Posteriorly the dorsal surface of the nuchal bone was covered entirely by a large first vertebral scute. The dorsal profile of the nuchal bone is gently concave. Ventrally the fine reticulate ornament and scute seams extend posteriorly for $20 \mathrm{~mm}$ before reaching the crescent-shaped scar that marks the attachment of the skin to the ventral surface of the carapace. The portion of the cervical scute that continues onto the ventral surface of the carapace is strongly narrowed relative to the dorsal portion. Its width is 51 per cent of the dorsal portion of the scute. The anterior rim of the nuchal is not curved dorsally, unlike the margins of all the known peripherals.

210 Costal bones. There are several costal bone fragments, of which NTM P5377, the proximal end of a right costal 7, is the most informative (Figure 3A-D). The costal bone extends all the way to the midline indicating that there was no exposed neural bone on the midline. Other fragments from the medial ends of costals also lack an exposed neural bone, indicating that there were at most one or two discontinuous exposed neurals, if any at all. Dorsally the bone is traversed by a single longitudinal seam that in life divided the fourth pleural scute from the fourth or fifth vertebral scute. The dorsal surfaces of all of the costal bones are rugose with rounded irregular ridges that tend to become elongated and transversely aligned toward the distal end (fig. 3E).

218 These replace the rounded flat tubercles separated by a network of finely etched grooves that are 219 seen on the ventral surface of the plastron and the dorsal surface of some of the peripherals. A 220 fossa with a sharp anterior rim excavates the ventral surface along the posterior margin, near the 221 medial end. This represents the anterior part of the iliac scar. The medial ends of this specimen 222 and other costal bones do not curve ventrally indicating that a longitudinal median furrow was 223 not present.

224 Peripheral bones. All of the preserved peripheral bones (NTM P5337, P5371, 5373 and P5378) 225 have dorsally curved margins. The anterior most preserved peripheral (NTM P5337) is almost 226 certainly peripheral 2 (Fig. 4A-F), while the posterior most one (NTM P5373) is probably a 227 peripheral 10 based on the sinuous posterior sutural line that would have contacted the pygal 
228

229

230

231

232

233

234

235

236

237

238

239

240

241

242

243

244

245

246

247

248

249

250

251

252

253

254

255

256

257

258

259

260

261

262

263

264

265

266

267

(Fig. 4G-L). These indicated that the upcurved margins of the shell extended well anterior and posterior of the bridge. The margin of peripheral 2 is particularly strongly curved, similar to the degree displayed by peripherals from the bridge region of $C$. (C.) longicollis even though this specimen is clearly not from the bridge (fig. 4B). The dorsal surface of the peripherals is ornamented with fine irregular rugae (e.g. NTM P5337, Fig. 4A) or a fine reticulate ornament of the same type seen on the surface of the bones of the plastron (e.g. NTM P5373, Fig. 4G).

\section{Plastron}

Like the carapace the plastron is only known from isolated elements. However, unlike the carapace, enough pieces are known from similar sized individuals to produce a reconstruction (Fig. 5).

Epiplastron. The epiplastron is represented by the holotype, NTM P5364 (Fig. 1, Table 1). It is a roughly elliptical plate with a rounded convex anterolateral margin. The margin forms a thin sharp edge that is weakly reflexed ventrally at its posterior end where it forms the anterolateral margin of the humeral scute. The ventral curvature of the margin becomes more strongly developed anteriorly, along the anterolateral margin of the gular scute. Anteriorly the ventral surface is crossed by the seam between the gular and intergular scutes. This seam reaches the median symphyseal line posterior to the anterior margin indicating that the intergular scute was retracted from the anterior margin and the two gular scutes had an anterior midline contact. However this midline contact appears to have been rather short, with a pointed anterior process of the intergular scute intruding deeply between the pair. The posterior end of the epiplastron is damaged but a seam line can be seen clearly curving from the lateral margin of the intergular scute toward the lateral margin of the epiplastron. This seam forms the posterior border of the humeral scute and indicates that the pectoral scute extended onto the posterior surface of the epiplastron. The humeral-pectoral scute seam meets the humeral-intergular scute seam at the medial margin of NTM P5364, but this is clearly a broken edge, not the sutural surface that contacts the entoplastron. Therefore the triple junction of the humeral, pectoral and intergular scute occurs on the epiplastron.

Hyoplastron. The complete hyoplastron (NTM P5369) is the largest single piece of turtle shell recovered from Alcoota (Fig. 6, Table 1). It represents a moderately small turtle with a plastron width at the level of the axial notches of about $105 \mathrm{~mm}$. The anterior lobe expands slightly laterally, anterior to the axial notch as in adult C. (C.) canni (McCord \& Thomson, 2002), though not to the extreme displayed by $C$. (C.) longicollis (e.g. NTM R27168). In lateral view the anterior lobe is slightly upcurved. Its margin is a simple edge that is not ventrally reflexed as in the margin of the epiplastron. A strongly developed seam representing the junction of the abdominal and pectoral scutes extends transversely across the ventral surface, approximately one quater of the length of the bone from its posterior margin. The seam curves posteriorly as it approaches the medial symphyseal suture. There is no seam present near the anteromedial corner of the bone where the medial symphysis meets the suture between the hyoplastron and the entoplastron. This indicates that the posterior end of the intergular scute terminated on the entoplastron and did not extend onto the hyoplastra as it does in $C$. (C.) canni (pers. obs., NTM 
R16325). Anteriorly the hyolplastron forms a short jagged sutural surface that contacted the epiplastron. Lateral to the triangular notch in this suture, the ventral surface is marked by a seam that extends from the hyoplastron-epiplastron suture to the lateral margin of the hyoplastron. This indicates that the posterolateral corner of the humeral scute extended onto the hyoplastron. Because the humeral-pectoral scute seam intersects the hyoplastron-epiplastron suture rather than extending transversely to the hyoplastron-entoplastron suture, the pectoral scute must have extended onto the epiplastron, as is shown by the epiplastron from Alcoota (NTM P5364). The axial notch extends for slightly less than half the length of the hyoplastron. The bridge region, posterior and lateral to the axial notch is set at a very broad angle to the ventral plate of the hypolastron. Although some crushing may have further flattened the hypolastron it seems likely that the shell was quite dorsoventrally shallow in life. The anterior end of the bridge region curves sharply dorsally and medially to form the anterior bridge strut. No distinct line can be seen on this surface marking the attachment of the dermis. A rounded notch that is $1.7 \mathrm{~mm}$ across excavates the anterodorsal margin of the bridge at the point that it curves medially to form the anterior bridge strut (Fig. 7C). This notch would have formed a complete foramen when articulated with the third peripheral. Extant Chelodina have a well developed foramen in the same position to allow for the passage of the axillary duct of Rathke's gland (Goode, 1967; Weldon \& Gaffney 1998). The sutural surface of the anterior bridge strut that contacted the carapace is tear-drop shaped with a strongly expanded medial end. The medial projection of the anterior bridge strut is great enough to be confident that it would have made broad contact with the ventral surface with the first costal bone when articulated with the carapace.

Hypoplastron. The hypoplastron is represented by three specimens, all of which are damaged. The main body is a roughly square plate with a laterally protruding bridge process (Figs. 8, 9). The ventral surface of the main body is traversed by a straight transverse seam, dividing the abdominal scute from the femoral scute. The lateral end of the seam terminates at the rounded inguinal notch between the body and the bridge process. Posterior to the inguinal notch the lateral margin of the femoral scute is produced laterally to form a modest semilunate flange. As in the hyoplastron the bridge is set at a very broad angle to the main body, indicating a markedly shallow shell not unlike $C$. (C.) steindachneri.

Xiphiplastron. The single complete xiphiplastron (NTM P5374) is a flat trapezoidal plate (Fig. 10 , Table 1). The ventral surface was largely covered by the anal scute with a narrow band of the femoral scute covering the anterior end of the bone. The lateral margin is damaged in the middle but the posterior and anterior ends of the lateral margin are complete. These show that the lateral margin in the region of the femoral scute was in line with the posterior lateral margin of the anal scute and did not project laterally to form a femoral bulge like some chelodinines such as Chelodina (Chelodina) longicollis and Birlimarr gaffneyi (Megirian \& Murray, 1999). The posterolateral corner is moderately thickened and upturned. It is not extended posteriorly and the lateral and posterior margins meet to form a right-angled corner. Mirror-imaging (Fig. 10E) indicates that the anal notch was triangular. The dorsal surface bears sutural scars for the ischium and pubis. The pubic scar is centrally located in the anterior half of the xiphiplastron and is roughly oval and oriented with its long axis extending obliquely anteromedial to posterolateral. 
309

310

311

\section{Discussion}

\section{Phylogenetic relationships}

314 The midline contact of the gular scutes anterior to the intergular is a well-known synapomorphy

315 of Chelodina (Gaffney, 1977, 1981; Georges \& Thomson, 2010). The rounded posterolateral

316 margin of the ischiadic scar on the xiphiplastron is a further synapomorphy of Chelodina

317 (Lapparent de Broin \& Molnar, 2001). Finally the enlargement of the axillary scent gland

318 foramen would appear to be also a synapomorphy of Chelodina. The foramen is large in

319 Chelodina (Chelodina) (e.g. diameter of $2.2 \mathrm{~mm}$ in C. (C.) longicollis; NTM R27168) and

320

321

322

323

324

325

326

327

328

329

330

331

332

333

334

335

336

337

338

339

340

341

342

343

344

345
Chelodina (Macrochelodina) (e.g. C. (M.) expansa; Goode, 1967, fig. 134) whereas it is comparatively tiny in members of the short-necked clade (e.g. diameter of $0.9 \mathrm{~mm}$ in Emydura sp.; NTM unregistered) (Fig. 7A).

Lateral widening of the anterior lobe of the plastron is a character that has only been observed among members of the nominal subgenus (e.g. C. (C.) longicollis and C. (C.) canni) and is probably a synapomorphy of the subgenus that reverses in some members of the $C$. (C.) novaeguineae species complex. Further supporting a position within $C$. (Chelodina), the length of the intergular scute was almost certainly greater than twice the length of the seam between the pectoral scutes. In short-necked chelodinines the ratio of the length of the intergular scute to the length of the shared pectoral seam ranges from 0.55 (Emydura sp.) to 1.35 (Pseudemydura umbrina) a range that overlaps with the range of 1.14 to 1.53 seen in Chelodina (Macrochelodina) (Table 2). C. (Macrodiremys) colliei also falls in this range with a ratio of 1.43. Thus a ratio of less than 2 is clearly primitive for Chelodininae. In contrast all members of $C$. (Chelodina) have an intergular scute that is more than twice the length of the shared pectoral seam and can range up to 5.35 times longer in $C$. (C.) canni (Table 2).

The state of this character can be determined in C. (Chelodina) murrayi despite the fragmentary nature of the material. The length of the junction between the pectoral scutes on the hyoplastron (P5369) is $28 \mathrm{~mm}$. Because the intergular scute extends close to the posterior end of the entoplastron in all Chelodina, the total length of the pectoral scute junction in life could not have been more than a few millimetres longer than the length of the seam present on the hyoplastron. The depth of the notch in the anterior margin of the hyoplastron for receiving the entoplastron is $27 \mathrm{~mm}$. Thus the midline length of the intergular scute was approximately $27 \mathrm{~mm}$ plus an unknown length that protruded anteriorly between the epiplastra. There is $18 \mathrm{~mm}$ of intergular scute overlapping the midline suture of the epiplastron. Because the width of this epiplastron from the midline to the lateral edge is a good match for the width of the anterior end of the hyoplastron (Fig. 6A) they must derive from similar sized individuals or possibly even the same 
346

347

348

349

350

351

352

353

354

355

356

357

358

359

360

361

362

363

364

365

366

367

368

369

370

371

372

373

374

375

376

377

378

379

380

381

382

383

384

individual. Thus we can be confident that the length of the intergular in an individual the size of P5369 or P 5364 was $45 \mathrm{~mm}(18+27)$ plus an unknown length between the anterior end of the hyoplastron and the posterior end of the midline suture between the epiplastra. Thus, even when the unknown segment of the intergular is ignored, the ratio of intergular to the shared pectoral seam exceeds the ratio of 1.5 which lies at the upper end of the range in Chelodina (Macrochelodina) and Chelodina (Macrodiremys). Indeed the reconstruction suggests that the total length of the intergular was likely to be around $65 \mathrm{~mm}$, which is 2.3 times the length of the shared seam between the pair of pectoral scutes.

Finally supporting the subgeneric placement of $C$. (C.) murrayi is the absence of a distinct line demarcating the attachment of the dermis on the anterior surface of the anterior bridge strut. In short-necked chelodinines (fig. 7A) and in Chelodina (Macrochelodina) ssp. (pers. obs., NTM R35010, NTM R24813) there is a distinct, sharp line extending anterodorsally from the axillary notch to the peripherals of the carapace that indicates the position that the dermis attached to the shell and divides the ornamented external surface from the smooth inner surface. In Chelodina (Chelodina) however there is no distinct line and the external surface merges gradually with the internal surface (pers. obs., NTM R16325, R27168; Fig. 7B). The latter condition would appear to be the derived one and is a further synapomorphy of Chelodina (Chelodina).

Within Chelodina (Chelodina) the large medially inflected and terminally expanded anterior bridge strut of the hyoplastron indicate that its relationships lie with the $C$. (C.) novaeguineae species complex (McCord \& Thomson 2002). McCord and Thomson included C. (C.)

novaeguineae, $C$. (C.) canni, C. (C.) reimanni and C. (C.) mccordi in this complex. I also include C. (C.) pritchardi because it has a large anterior bridge strut that contacts the first costal (Rhodin 1994a) and is more closely related to other members of the complex than it is to either $C$. (C.) longicollis or C. (C.) steindachneri (Georges, Adams \& McCord, 2002). The condition in basal species of the subgenus, i.e. (C. (C.) longicollis and $C$. (C.) steindachneri, is to have reduced anterior bridge struts that do not extend far medially and fail to contact the costal bones (Thomson, 2000). The same condition obtains in C. (Macrodiremys) colliei (Thomson, 2000) which is the sister group to $C$. (Chelodina), indicating that reduced anterior bridge struts are primitive condition for the subgenus. Thus the $C$. (C.) novaeguineae species complex have apparently reversed this condition and have medially extensive anterior bridge struts that broadly contact the costal bones like those of Chelodina (Macrochelodina) and short-necked chelodinines (Thomson, White \& Georges, 1997; McCord \& Thomson 2002).

\section{Unity of the hypodigm}

It is obvious that much of the diagnosis and description of the new taxon is reliant upon the referral of several unassociated specimens to a single taxon. It should be noted that even if there was more than one turtle taxon present at Alcoota, Chelodina (Chelodina) murrayi would still stand as a valid taxon because the holotype epiplastron displays an autapomorphy as well as a synapomorphy of Chelodina. Nevertheless the referral of the Alcoota turtle sample to a single species is the most likely hyopothesis based on the following observations.

PeerJ reviewing PDF | (v2013:06:594:2:0:ACCEPTED 12 Sep 2013) 
Firstly multiple elements (the epiplastron, hyoplastron and the xiphiplastron) display synapomorphies of Chelodina: anteriorly enclosed intergular scute (Fig. 1A), enlarged foramen for Rathke's gland (Fig. 7C), rounded posterlateral margin of ischiadic scar (Fig. 10B, D). The hyoplastron also shows additional synapomorphies of Chelodina (Chelodina): lateral expansion of anterior lobe of plastron, absence of a distinct line of attachment of the dermis on the anterior bridge strut and a short pectoral-pectoral scute seam.

Other elements display plesiomorphies that are only present in Chelodina or Pseudemydura among Chelodininae. These plesiomorphies include the extension of the pectoral scute onto the posterior end of the epiplastron, a triple junction between the humeral, pectoral and intergular scute located on the epiplastron and a skin-carapace contact on the nuchal bone that lies posterior to the anterior margin of the carapace. None of the preserved elements show any characters of the distinctive Pseudemydura, thus these plesiomorphies add further support to the conclusion that most, if not all, of the Alcoota chelid specimens belong to Chelodina.

None of the preserved elements show any characters that are inconsistent with referral to Chelodina (Chelodina). These observations strongly suggest that only Chelodina (Chelodina) is present in the Alcoota assemblage. Extant Chelodina (Chelodina) species have almost exclusively allopatric ranges (Kennet et al., 1992; Rhodin 1994a\&b; McCord \& Thomson, 2002; Georges \& Thomson, 2010). The Fitzroy-Dawson drainage includes hybrids between $C$. (C.) canni and $C$. (C.) longicollis and would appear to represent the sole river system where two species of Chelodina (Chelodina) overlap (Georges, Adams \& McCord, 2002). Thus it is very unlikely that more than one species of Chelodina (Chelodina) is present in the Alcoota local fauna and the hypodigm of $C$. (C.) murrayi can be safely treated as pertaining to a single species.

\section{Biogeography and Evolution of Chelodina (Chelodina)}

Extant members of the $C$. (C.) novaeguineae complex are restricted to the far north of Australia (C. (C.) canni), New Guinea (C. (C.) novaeguineae, C. (C.) reimanni and C. (C.) pritchardi) and Indonesia $(C$. (C.) mccordi). The presence of $C$. (C.) murrayi at Alcoota indicates that this clade extended further south in the past. At present it is not possible to determine if $C$. (C.) murrayi is an unusual southerly extension of an otherwise tropical clade, or whether the species group originated south of its present range and only later radiated in the tropics to the north of continental Australia.

The presence of a member of the $C$. (C.) novaeguineae species complex in the late Miocene indicates that stem members of $C$. (C.) steindachneri and $C$. (C.) longicollis were in existence at this time and their divergence was not related to climatic fluctuations of the Pleistocene as has been suggested (Kennet et al., 1992).

\section{Palaeobiology}

Among chelodinines it is the members of Chelodina (Chelodina) that are best able to cope with unpredictable drying events. C. (C.) steindachneri occupies some of the most arid habitats of any chelodinine, where surface water is ephemeral and infrequent (Cann, 1998). C. (C.) longicollis and C. (C.) canni are reported to travel many kilometres over land (Stott, 1987; Covacevich, 
424 1990) and are capable of prolonged aestivation (Bill Cook, reported in Kennet et al., 1992; Roe \& 425 Georges, 2007).

426 It is therefore unsurprising to find that the Alcoota chelid belongs to Chelodina (Chelodina)

427 because palaeoenvironmental indicators suggest that surface water in the Waite Basin, during the

428 late Miocene, was prone to episodic drying events. It is notable that the Alcoota assemblage does

429 not contain any fish. While a preservational bias may account for the lack of smaller fish bones it

430 does not explain the absence of robust lungfish toothplates which are generally abundant in

431 freshwater deposits throughout central and eastern Australia from the late Oligocene through to

432 the Pleistocene (Kemp, 1991, 1993). The lack of lungfish toothplates therefore indicates that

433 surface water at the Alcoota site was not permanent. Other aquatic taxa are scarce. Chelodina

434 (Chelodina) murrayi itself requires a minimum of just two individuals to account for its known

435 remains. Crocodiles are present, but these are massive, altirostral, semiziphodont mekosuchins of

436 the genus Baru (pers. obs.) with clear indications that they specialised on large vertebrate prey

437 (Willis, Murray \& Megirian, 1990) and thus may not have been as strongly tied to deep

438 permanent water as extant crocodylids are.

\section{Conclusions}

440 The chelid material from the late Miocene Alcoota Local Fauna of central Australia can be

441 referred to a single species that is here named Chelodina (Chelodina) murrayi. Within the

442 subgenus, the affinities of the new species lie with the $C$. (C.) novaeguineae species complex

443 which now occurs in tropical habitats to the north of Alcoota (mostly outside continental

444 Australia). Thus both the subgenus, and the $C$. (C.) novaeguineae species complex were more

445 widespread in the past and diversification of the extant species began prior to the late Miocene.

\section{Acknowledgements}

447 This work would not have been possible without the immense effort put into running the Alcoota 448 field program for over two decades by P. Murray and D. Megirian. Many people have

449 participated in these excavations over the years but J. Archibald stands out as the collector of the 450 holotype and several other important pieces of Chelodina (Chelodina) murrayi. Access to 451 comparative specimens was facilitated by G. Dally and S. Horner. S. Thomson alerted me to the 452 nomenclatural complications surrounding Chelodininae and its primary author.

\section{References}

454 Archer M, Godthelp H, Hand SJ, Megirian D. 1989. Preliminary overview of mammalian 455 diversity, biostratigraphy, correlation and environmental change evidenced by the fossil deposits 456 of Riversleigh, northwestern Queensland, Australia. Australian Zoologist 25: 29-64 
457 Baur G. 1893. Notes on the classification and taxonomy of the Testudinata. Proceedings of the

458 American Philosophical Society 31: 210-225.

459 Burbidge AA, Kirsch JAW, Main AR. 1974. Relationships within the Chelidae (Testudines:

460 Pleurodira) of Australia and New Guinea. Copeia 1974: 392-409.

461 Cann J. 1998. Australian Freshwater Turtles. Singapore: Beaumont Publishing.

462 Cogger HG. 1975. Reptiles and Amphibians of Australia. Sydney: Reed.

463 Covacevich J, Couper P, McDonald K., Trigger D. 1990. Walunarra, Bungarra mali, and the 464 Gangalidda at Old Doomadgee. Memoirs of the Queensland Museum 29: 322.

465 Gaffney ES. 1977. The side-necked turtle family Chelidae: A theory of relationships using shared 466 derived characters. American Museum Novitates 2620: 1-28.

467 Gaffney ES. 1981. A review of the fossil turtles of Australia. American Museum Novitates 2720:

$468 \quad 1-38$.

469 Gaffney ES, Archer M, White A. 1989. Chelid Turtles from the Miocene Freshwater Limestones 470 of Riversleigh Station, Northwestern Queensland, Australia. American Museum Novitates 2959: 471 1-10.

472 Georges A, Adams M, McCord W. 2002. Electrophoretic delineation of species boundaries within 473 the genus Chelodina (Testudines: Chelidae) of Australia, New Guinea and Indonesia. Zoological 474 Journal of the Linnean Society 134: 401-421.

475 Georges A, Birrell J, Saint KM, McCord W, Donnellan SC. 1998. A phylogeny for side-necked 476 turtles (Chelonia: Pleurodira) based on mitochondrial and nuclear gene sequence variation.

477 Biological Journal of the Linnean Society 67: 213-246.

478 Georges A, Thomson S. 2010. Diversity of Australasian freshwater turtles, with an annotated 479 synonymy and keys to species. Zootaxa 2496: 1-37.

480 Goode J. 1967. Freshwater tortoises of Australia and New Guinea (in the family Chelidae). 481 Melbourne: Lansdowne Press.

482 Kemp A. 1991. Australian Mesozoic and Cainozoic lungfish. In: Vickers-Rich P, Monaghan JM, 483 Baird RF, Rich TH, eds. Vertebrate Palaeontology of Australasia. Lilydale: Pioneer Design 484 Studio, 465-496.

485 Kemp A. 1993. Ceratodus diutinus, a new ceratodont from Cretaceous and Late Oligocene486 medial Miocene deposits in Australia. Journal of Palaeontology 67: 883-888.

487 Kennet RM, Georges A, Thomas K, Georges TC. 1992. Distribution of the long-necked 488 freshwater turtle Chelodina novaeguineae and new information on its ecology. Memoirs of the 489 Queensland Museum 32: 179-182. 
490 Lapparent de Broin F, Molnar RE. 2001. Eocene chelid turtles from Redbank Plains, Southeast

491 Queensland, Australia. Geodiversitas 23: 41-79.

492 McCord WP, Thomson SA. 2002. A New Species of Chelodina (Testudines: Pleurodira:

493 Chelidae) from Northern Australia. Journal of Herpetology 255-267.

494 Megirian D, Murray P, Wells R. 1996. The Late Miocene Ongeva Local Fauna of central

495 Australia. The Beagle: Records of the Museums and Art Galleries of the Northern Territory 13: 9-

49638.

497 Megirian D, Prideaux G, Murray PF, Smit N. 2010. An Australian land mammal age

498 biochronological scheme. Paleobiology 36: 658-671.

499 Megirian D, Murray P. 1999. Chelid turtles (Pleurodira, Chelidae) from the Miocene Camfield

500 Beds, Northern Territory of Australia, with a description of a new genus and species. The Beagle:

501 Records of the Museums and Art Galleries of the Northern Territory 15: 75-130.

502 Murray PF, Megirian D. 1992. Continuity and contrast in middle and late Miocene vertebrate

503 communities from the Northern Territory. The Beagle: Records of the Museums and Art Galleries

504 of the Northern Territory 9: 195-218.

505 Murray PF, Vickers-Rich P. 2004. Magnificent Mihirungs: the Colossal Flightless Birds of the

506 Australian Dreamtime. Bloomington: Indiana University Press.

507 Newsome AE, Rochow KA. 1964. Vertebrate fossils from Tertiary sediments in central Australia.

508 The Australian Journal of Science 26: 352.

509 Philippen H-D, Grossmann P. 1990. Eine neue Schlangenhalsschildkröte von Neuguinea:

510 Chelodina reimanni sp. n. (Reptilia, Testudines, Pleurodira: Chelidae). Zoologische

511 Abhandlungen. Staatliches Museum für Tierkunde, Dresden 46: 95-102.

512 Rhodin AGJ. 1994a. Chelid turtles of the Australasian Archipelago: I. A new species of

513 Chelodina from southeastern Papua New Guinea. Breviora 497: 1-36.

514 Rhodin AGJ. 1994b. Chelid turtles of the Australasian Archipelago: II. A new species of 515 Chelodina from Roti Island, Indonesia. Breviora 498: 1-31.

516 Rhodin AGJ, Mittermeier RA. 1976. Chelodina parkeri, a new species of chelid turtle from New

517 Guinea, with a discussion of Chelodina siebenrocki, Werner 1901. Bulletin of the Museum of

518 Comparative Zoology 147: 465-488.

519 Roe JH, Georges A. 2007. Heterogenous wetland complexes, buffer zones, and travel corridors:

520 landscape management for freshwater reptiles. Biological Conservation 135: 67-76. 
521 Seddon JM, Georges A, Baverstock PR, McCord W. 1997. Phylogenetic relationships of chelid

522 turtles (Pleurodira: Chelidae) based on mitochondrial 12S rRNA gene sequence variation.

523 Molecular Phylogenetics and Evolution 7: 55-61.

524 Stott P. 1987. Terrestrial movements of the freshwater tortoise, Chelodina longicollis (Shaw), as

525 monitored with a spool tracking device. Wildlife Research 14: 559-567.

526 Thomson SA. 2000. A revision of the fossil chelid turtles (Pleurodira) described by C.W. de Vis, 527 1897. Memoirs of the Queensland Museum 45: 593-598.

528 Thomson SA, Georges A. 2009. Myuchelys gen. nov.: a new genus for Elseya latisternum and 529 related forms of Australian freshwater turtle (Testudines: Pleurodira: Chelidae). Zootaxa 2053: $530 \quad 32-42$.

531 Thomson S, White A, Georges A. 1997. Re-evaluation of Emydura lavarackorum: identification 532 of a living fossil. Memoirs of the Queensland Museum 42: 327-336.

533 Thomson, S.A. \& Mackness, B.S., 1999. Fossil turtles from the Early Pliocene Bluff downs 534 Local Fauna, with a description of a new species of Elseya. Transactions of the Royal Society of 535 South Australia 123, 101-105.

536 Weldon, P.J. \& Gaffney, E.S., 1998. An ancient integumentary gland in turtles.

537 Naturwissenschaften 85, 556-557.

538 White A. 1997. Cainozoic turtles from Riversleigh, northwestern Queensland. Memoirs of the 539 Queensland Museum 42: 413-422.

540 Willis PMA, Murray PF, Megirian D. 1990. Baru darrowi gen. et sp. nov., a large broad-snouted 541 crocodyline (Eusuchia: Crocodylidae) from mid-Tertiary freshwater limestones in northern 542 Australia. Memoirs of the Queensland Museum 29: 521-540.

543 Woodburne MO. 1967. The Alcoota Fauna, central Australia. Bulletin of the Bureau of Mineral 544 Resources Geology and Geophysics 87: 1-187. 
545 Figure 1. Holotype of Chelodina (Chelodina) murrayi sp. nov., right epiplastron, NTM P5364. A, 546 ventral view; B, dorsal view; $\mathbf{C}$, anterior view; D, posterolateral view; $\mathbf{E}$, interpretive drawing of

547 A; F, interpretive drawing of B. Arrow indicates ventrally curved marginal flange. Abbreviations:

$548 \mathrm{da}$, line of dermal attachment; g, gular scute; h, humeral scute; ig, intergular scute; p, pectoral

549 scute; sys, symphyseal surface. Hatched areas represent broken bone surfaces, grey areas

550 represent adherent matrix. Scale bar $=20 \mathrm{~mm}$.

551 Figure 2. Chelodina (Chelodina) murrayi sp. nov., nuchal bone, NTM P5370. A, dorsal view; B, 552 ventral view; $\mathbf{C}$, interpretive drawing of A; D, interpretive drawing of B. Abbreviations: ce, 553 cervical scute; da, line of the dermal attachment; $\mathrm{m1}$, first marginal scute; ssc1, sutural surface for 554 first costal bone; ssp1, sutural surface for first peripheral bone; v1, first vertebral scute. Hatched 555 areas represent broken bone surfaces. Scale bar $=20 \mathrm{~mm}$.

556 Figure 3. Chelodina (Chelodina) murrayi sp. nov., costal bones. A-D, proximal end of right 557 costal 7, (NTM P5377). A, dorsal view; B, ventral view; CD; E, distal end of right costal 2 (NTM 558 P5409) in dorsal view; F-I, interpretive drawings of A-D, respectively; J, Interpretive drawing of 559 E. Abbreviations: ia, iliac articulation surface; P1, P2, P4, first, second and fourth pleural scutes; 560 r, medial end of rib; rg, rib gomphosis; ss, symphyseal surface; ssc6, sutural surface for sixth 561 costal bone; sssp, sutural surface for suprapygal bone; V4, fourth vertebral scute; vps, vertebral562 pleural scute seam. Hatched areas represent broken bone surfaces, grey areas represent adherent 563 matrix. Scale bar $=20 \mathrm{~mm}$.

564 Figure 4 Chelodina (Chelodina) murrayi sp. nov., peripheral bones. A-F, left second peripheral, 565 (NTM P5337). A, dorsal view; B, ventral view; C, posterior view; D, interpretive drawing of A; 566 E, interpretive drawing of B; F, interpretive drawing of C; G-L, left tenth peripheral, (NTM 567 P5373). G, dorsal view; H, ventral view; I, anterior view; J, interpretive drawing of G; K, 568 interpretive drawing of $\mathrm{H}$; L, interpretive drawing of I. Abbreviations: da, line of the dermal 569 attachment; M2, M3, M10, M11, second, third, tenth and eleventh marginal scutes; P1, P4, first 570 and fourth pleural scutes; ssc1, ssc8, sutural surfaces for first and eighth costal bones; sspe3, 571 sspe9, sspe11, sutural surfaces for third, ninth and eleventh peripheral bones. Scale bar $=20 \mathrm{~mm}$.

572 Figure 5. Chelodina (Chelodina) murrayi sp. nov., reconstruction of plastron in ventral view. 573 Abbreviations: AB, abdominal scute; AN, anal scute; ent, entoplastron; epip, epiplastron; FE, 574 femoral scute; GU, gular scute; hyo, hyoplastron; hypo, hypoplastron; HU, humeral scute; IN, 575 intergular scute; PE, pectoral scute; xip,xiphiplastron. Grey areas represent areas of missing bone 576 that have been reconstructed. Scale bar $=50 \mathrm{~mm}$ 
577 Figure 6. Chelodina (Chelodina) murrayi sp. nov., left hyoplastron, NTM P5369. A, dorsal view;

$578 \mathbf{B}$, ventral view; $\mathbf{C}$, anterior view; D, lateral view; $\mathbf{E}$, interpretive drawing of A; F, interpretive 579 drawing of $\mathrm{B} ; \mathbf{G}$, interpretive drawing of $\mathrm{C} ; \mathbf{H}$, interpretive drawing of D. Abbreviations: $\mathrm{AB}$, 580 abdominal scute; abs, anterior bridge strut; HU, humeral scute; PE, pectoral scute; ssca, sutural 581 surface for articulation with the carapace; ssen, sutural surface of the entoplastron; ssep, sutural 582 surface of the epiplastron; sshy, sutural surface of the hypoplastron; sys, symphyseal surface. 583 Scale bar $=20 \mathrm{~mm}$.

584 Figure 7. Anterior bridge struts of various chelodinines in oblique, anterior-ventral-lateral view. 585 Top row: whole specimens with area of enlargement indicated by a box. Bottow row: 586 enlargement of anterior bridge strut area. A, Emydura sp., NTM unregistered comparative 587 collection; B, Chelodina (Chelodina) longicollis; C, Chelodina (Chelodina) murrayi. Dotted line 588 indicates likely extent of foramen for the axillary duct of Rathke's gland. Note that sediment 589 partly infills this notch. Abbreviations: da, line of dermal attachment; rgf, foramen for the axillary 590 duct of Rathke's gland.

591 Figure 8. Chelodina (Chelodina) murrayi sp. nov., left hypoplastron, NTM P5375. A, dorsal 592 (internal) view; B, ventral (external) view; C, Interpretive drawing of A; D, Interpretive drawing 593 of B. Abbreviations: AB, abdominal scute; b, bridge; FE, femoral scute; ssh, sutural surface for 594 the hyoplastron; ssx, sutural surface for the xiphiplastron; sys, symphyseal surface. Hatched areas 595 represent broken bone surfaces. Scale bar $=20 \mathrm{~mm}$.

596 Figure 9. Chelodina (Chelodina) murrayi sp. nov., left hypoplastron, NTM P9810. A, dorsal 597 (internal) view; B, ventral (external) view; C, Interpretive drawing of A; D, Interpretive drawing 598 of B. Abbreviations: AB, abdominal scute; b, bridge; FE, femoral scute; ssh, sutural surface for 599 the hyoplastron; ssx, sutural surface for the xiphiplastron; sys, medial symphyseal surface.

600 Hatched areas represent broken bone surfaces, grey areas represent patches of adherent matrix. 601 Scale bar $=20 \mathrm{~mm}$.

602 Figure 10. Chelodina (Chelodina) murrayi sp. nov., right xiphiplastron, NTM P5374. A, ventral 603 view; B, dorsal view; C, interpretive drawing of A; D, interpretive drawing of B; E,

604 reconstruction of articulated xiphiplastron pair in dorsal view. Abbreviations: AN, anal scute; FE, 605 femoral scute; sshy, sutural surface for hypoplastron; ssi, sutural surface for ischium; ssp, sutural 606 surface for pubis; sys, symphyseal surface; tm, possible tooth mark. Hatched areas represent 607 broken bone surfaces, grey areas represent areas of adherent matrix. Scale bar $=20 \mathrm{~mm}$ 


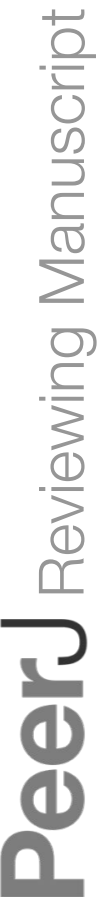

PeerJ reviewing PDF | (v2013:06:594:2:0:ACCEPTED 12 Sep 2013) 


\section{Figure 1}

Figure 1. Holotype of Chelodina (Chelodina) murrayi sp. nov., right epiplastron, NTM P5364.

A, ventral view; B, dorsal view; C, anterior view; D, posterolateral view; E, interpretive drawing of $A ; \mathbf{F}$, interpretive drawing of $B$. Arrow indicates ventrally curved marginal flange. Abbreviations: da, line of dermal attachment; g, gular scute; $h$, humeral scute; ig, intergular scute; $p$, pectoral scute; sys, symphyseal surface. Hatched areas represent broken bone surfaces, grey areas represent adherent matrix. Scale bar $=20 \mathrm{~mm}$. 


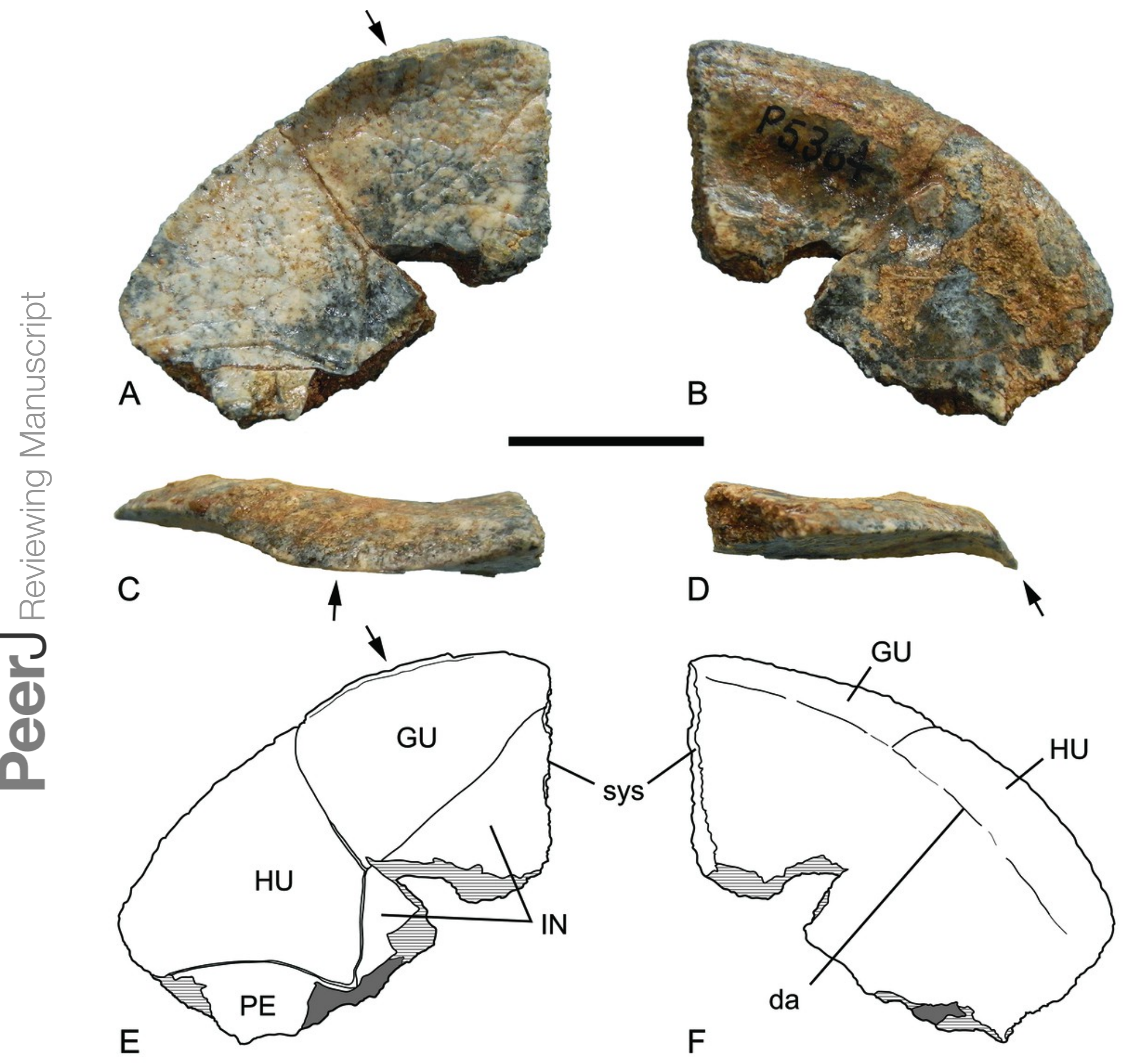




\section{Figure 2}

Figure 2. Chelodina (Chelodina) murrayi sp. nov., nuchal bone, NTM P5370.

A , dorsal view; $\mathbf{B}$, ventral view; $\mathbf{C}$, interpretive drawing of $\mathbf{A} ; \mathbf{D}$, interpretive drawing of $\mathbf{B}$. Abbreviations: ce, cervical scute; da, line of the dermal attachment; $\mathrm{m} 1$, first marginal scute; ssc1, sutural surface for first costal bone; ssp1, sutural surface for first peripheral bone; v1, first vertebral scute. Hatched areas represent broken bone surfaces. Scale bar $=20 \mathrm{~mm}$. 


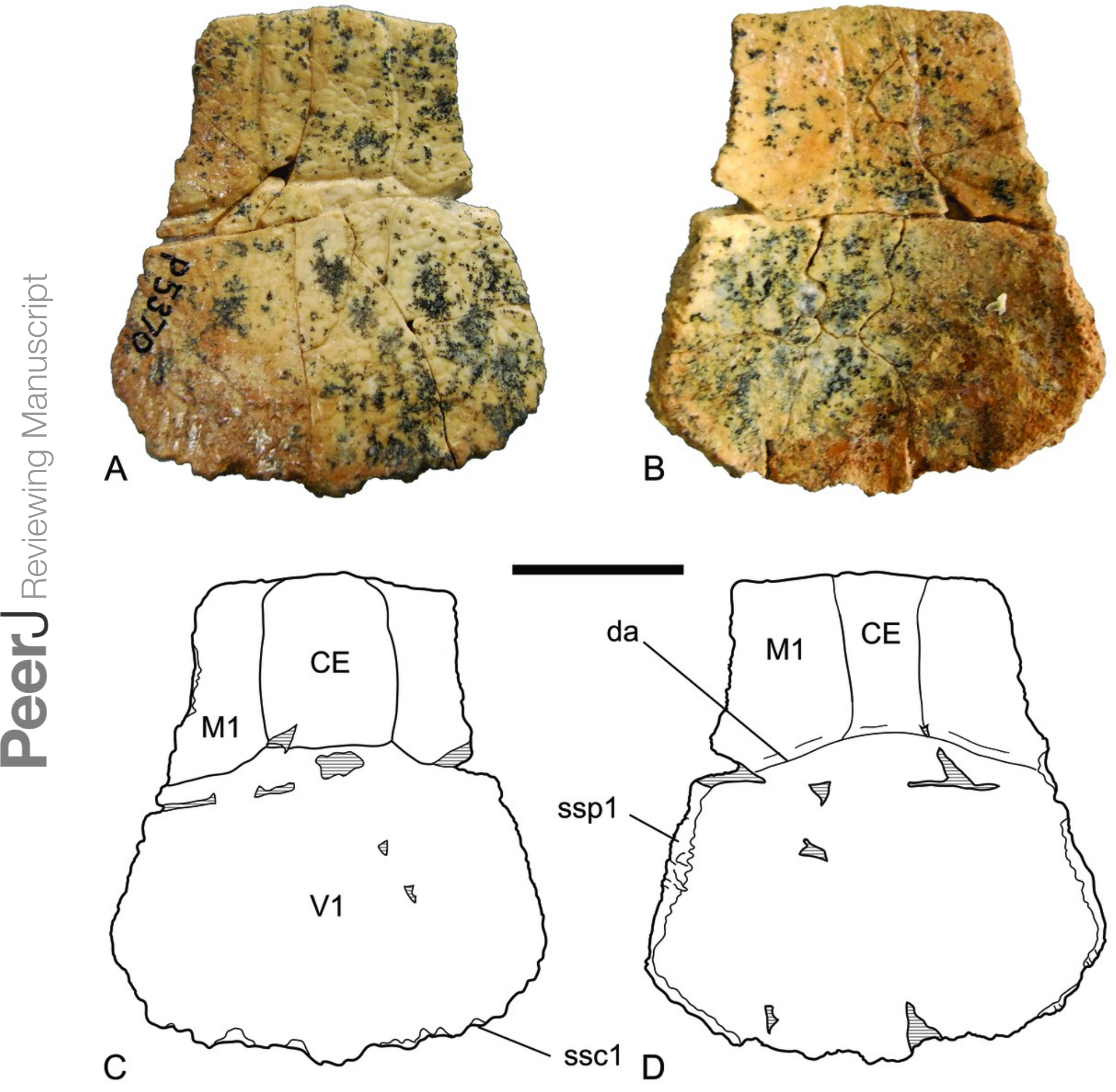




\section{Figure 3}

Figure 3. Chelodina (Chelodina) murrayi sp. nov., costal bones.

A -D, proximal end of right costal 7, (NTM P5377). A, dorsal view; B, ventral view; CD; E, distal end of right costal 2 (NTM P5409) in dorsal view; F-I, interpretive drawings of A-D, respectively; J, Interpretive drawing of E. Abbreviations: ia, iliac articulation surface; P1, P2, P4, first, second and fourth pleural scutes; r, medial end of rib; rg, rib gomphosis; ss, symphyseal surface; ssc6, sutural surface for sixth costal bone; sssp, sutural surface for suprapygal bone; V4, fourth vertebral scute; vps, vertebral-pleural scute seam. Hatched areas represent broken bone surfaces, grey areas represent adherent matrix. Scale bar $=20$ $\mathrm{mm}$. 


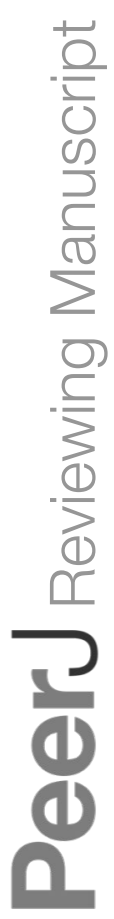

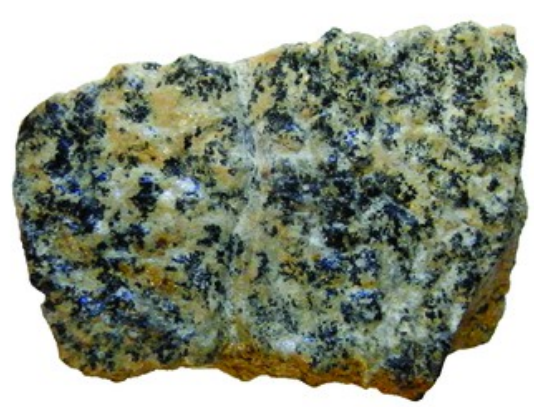

A

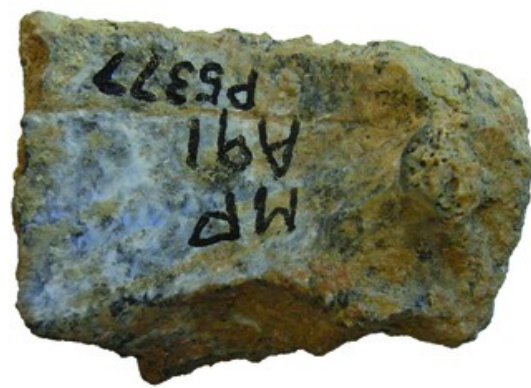

B

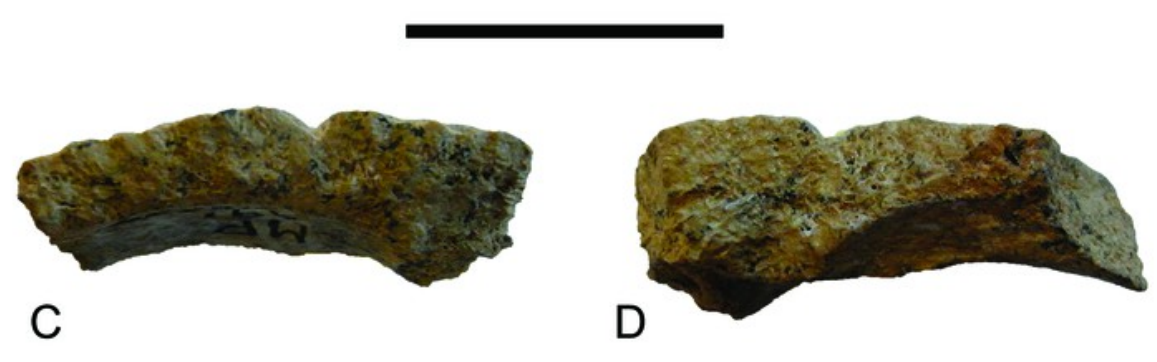

E
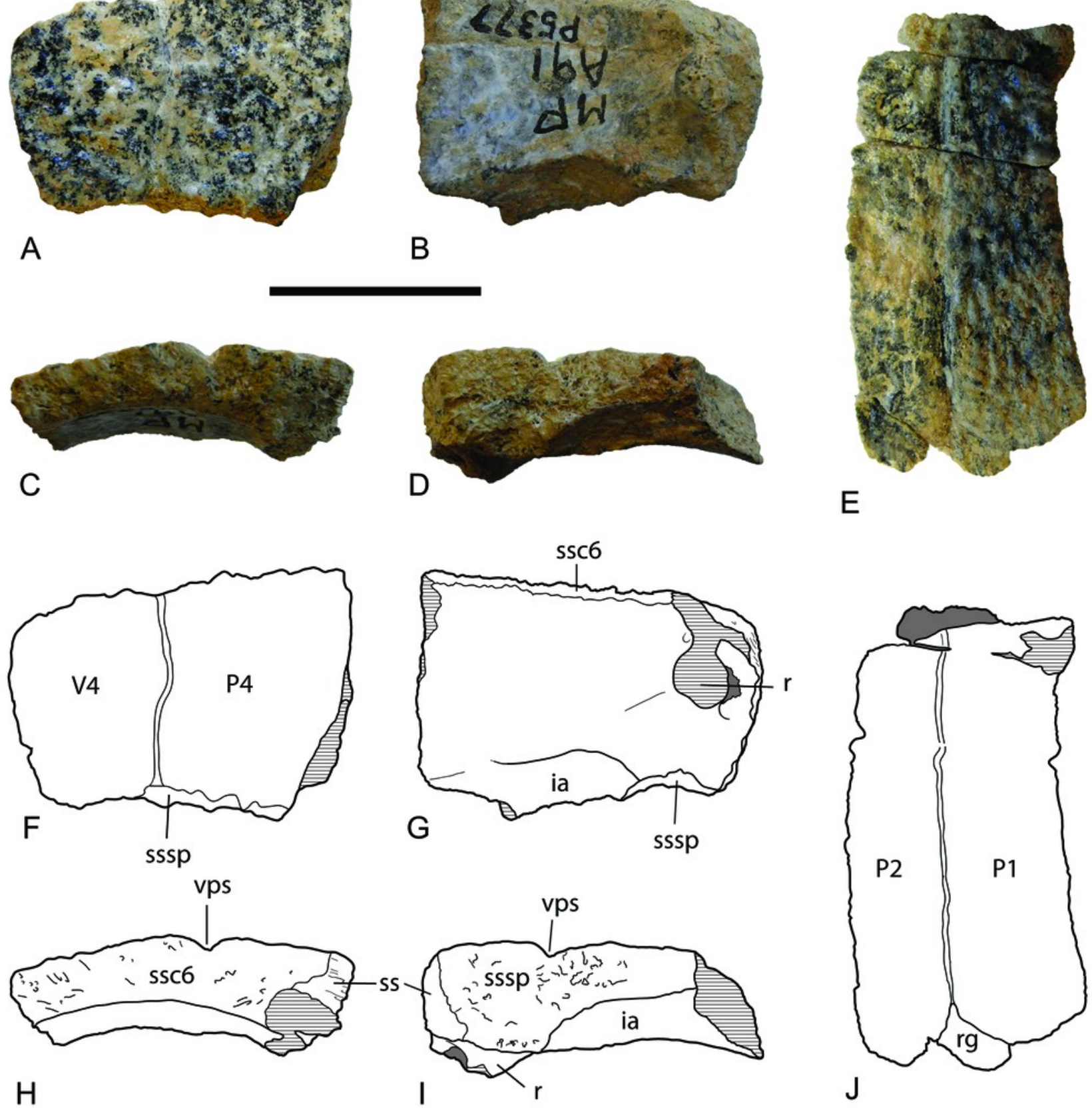


\section{Figure 4}

Figure 4 Chelodina (Chelodina) murrayi sp. nov., peripheral bones.

A-F , left second peripheral, (NTM P5337). A, dorsal view; B, ventral view; C, posterior view; $D$, interpretive drawing of $A ; E$, interpretive drawing of $B ; F$, interpretive drawing of $C ; G-L$, left tenth peripheral, (NTM P5373). G, dorsal view; H, ventral view; I, anterior view; J, interpretive drawing of $\mathrm{G} ; \mathrm{K}$, interpretive drawing of $\mathrm{H}$; $\mathrm{L}$, interpretive drawing of I. Abbreviations: da, line of the dermal attachment; M2, M3, M10, M11, second, third, tenth and eleventh marginal scutes; P1, P4, first and fourth pleural scutes; ssc1, ssc8, sutural surfaces for first and eighth costal bones; sspe3, sspe9, sspe11, sutural surfaces for third, ninth and eleventh peripheral bones. Scale bar $=20 \mathrm{~mm}$. 
A

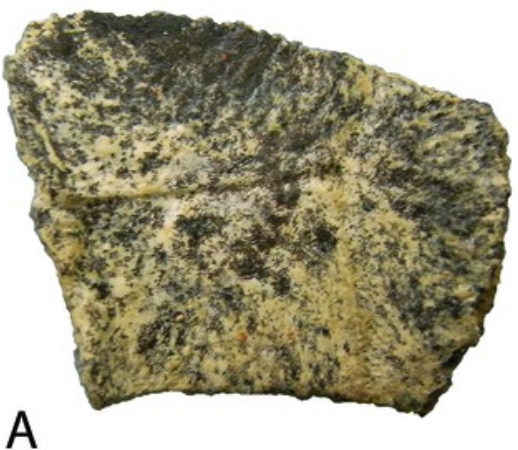

B
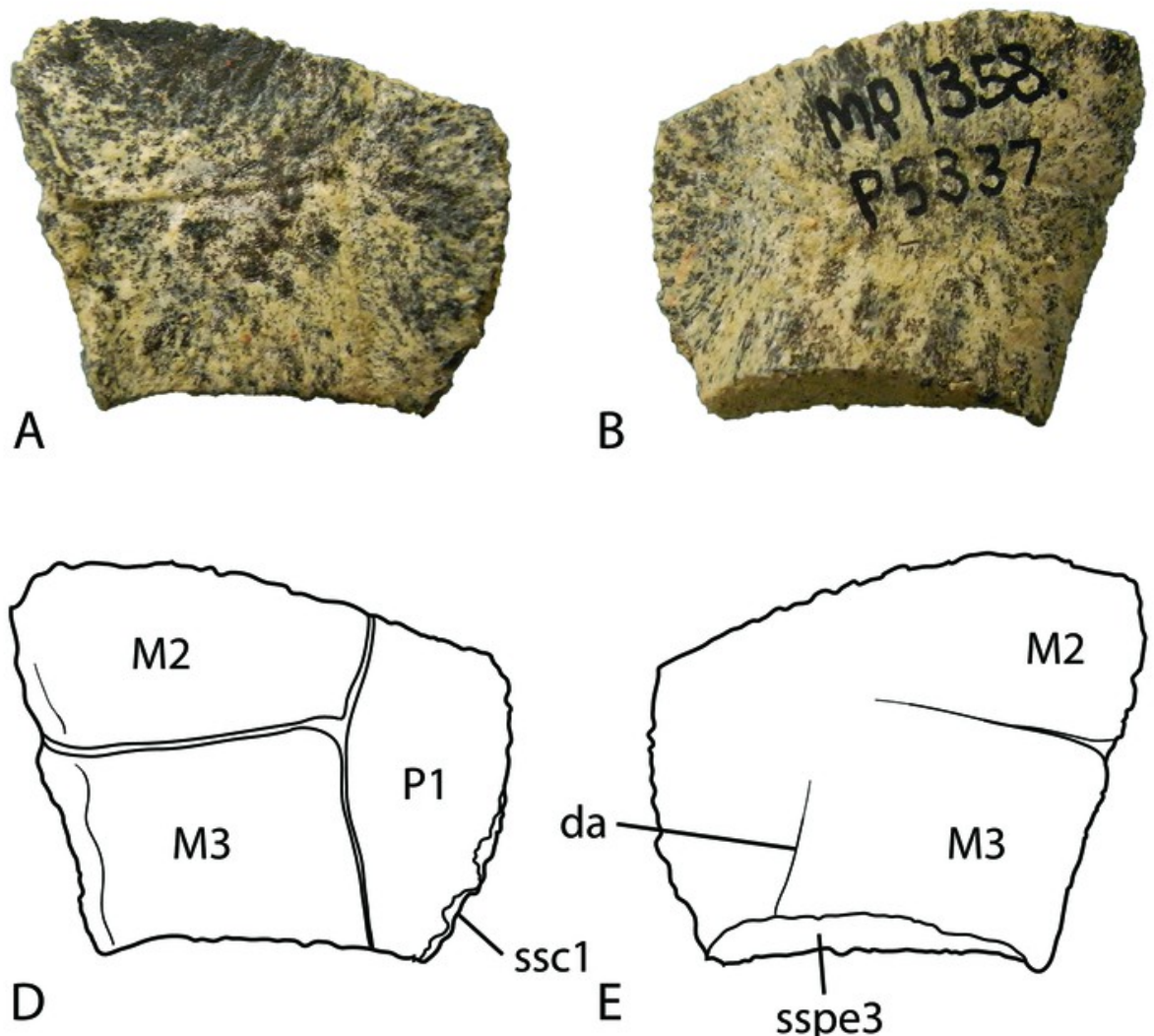

E
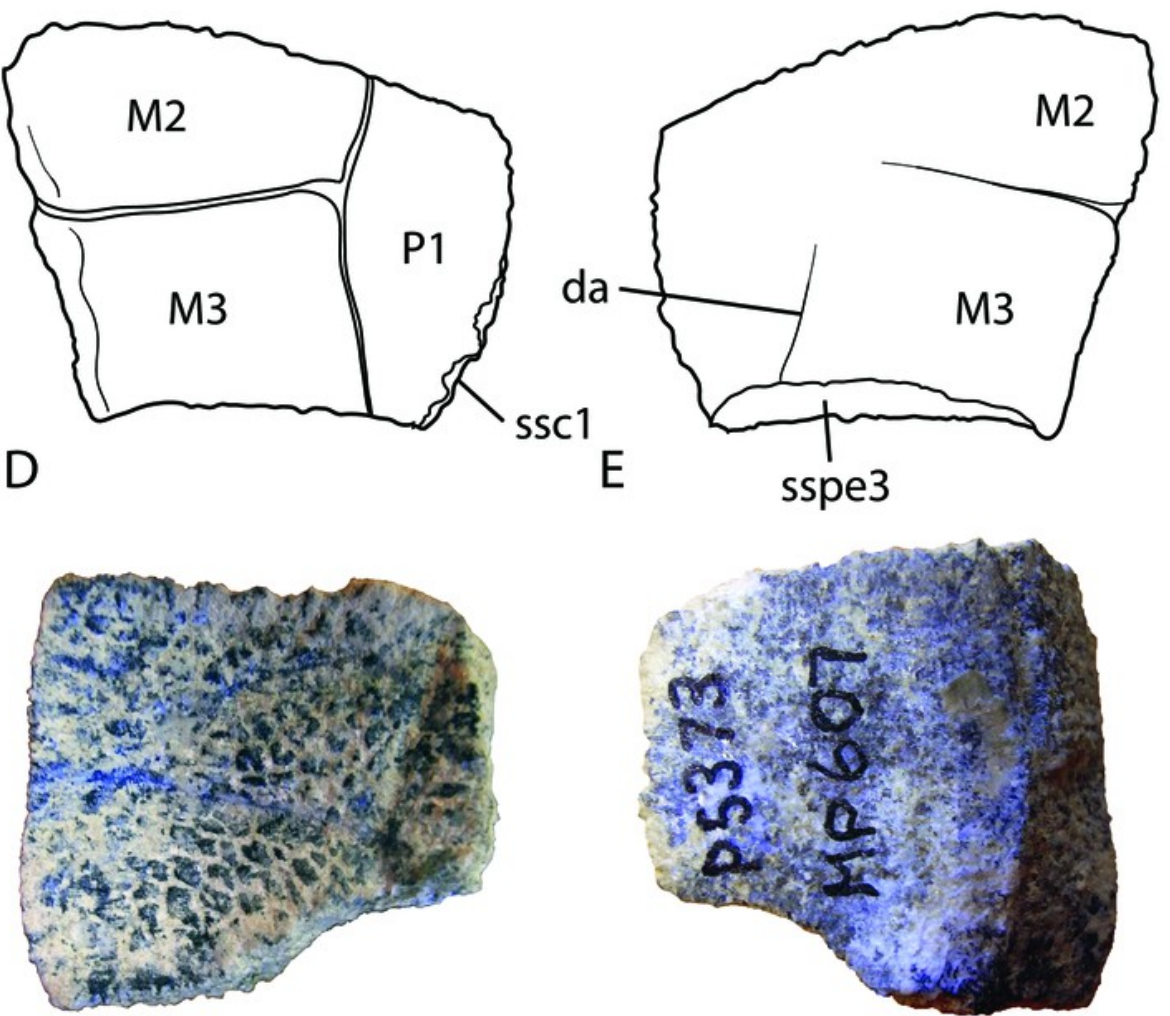

G
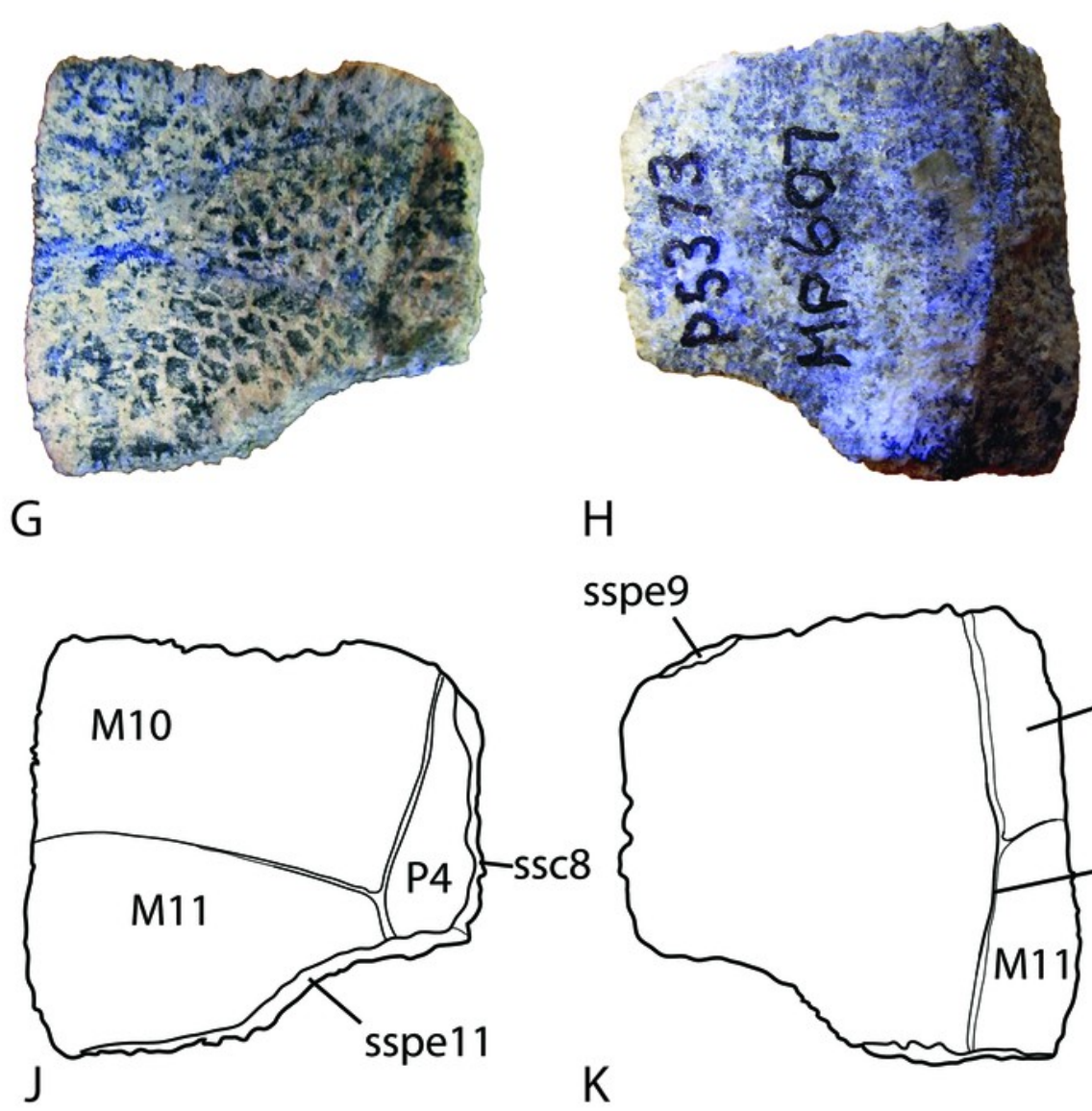

$\mathrm{H}$

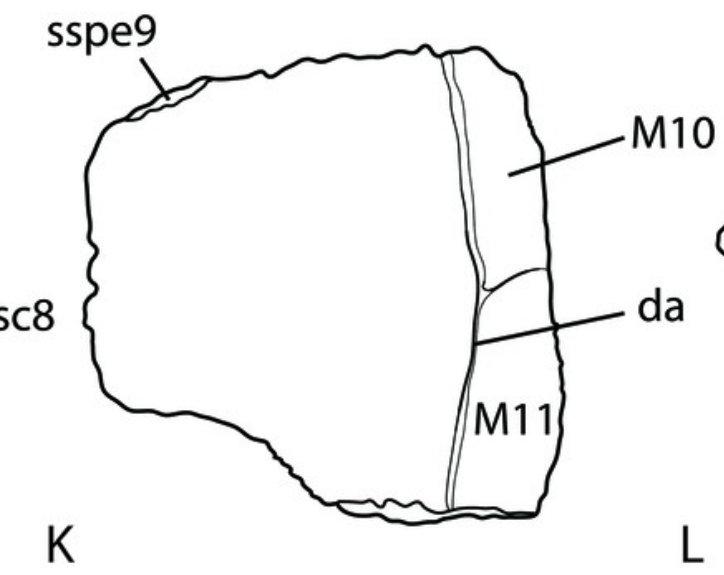

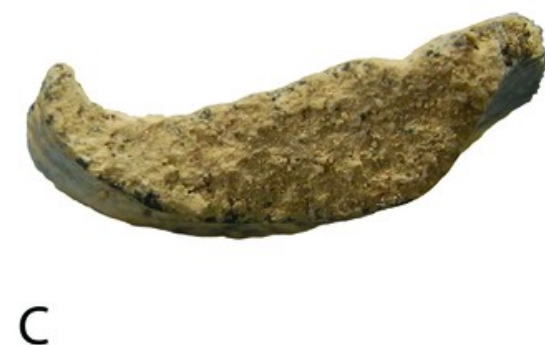

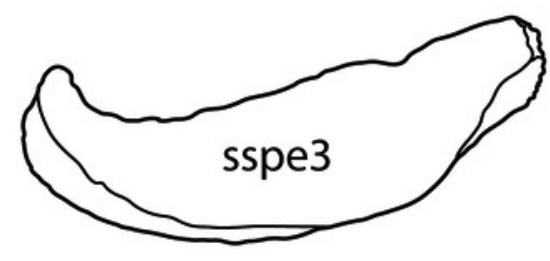

$\mathrm{F}$

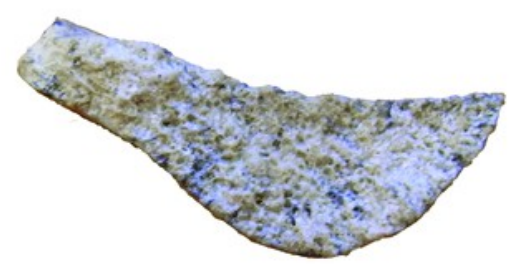

I 


\section{Figure 5}

Figure 5. Chelodina (Chelodina) murrayi sp. nov., reconstruction of plastron in ventral view.

Abbreviations: AB, abdominal scute; AN, anal scute; ent, entoplastron; epip, epiplastron; FE, femoral scute; GU, gular scute; hyo, hyoplastron; hypo, hypoplastron; HU, humeral scute; IN, intergular scute; PE, pectoral scute; xip,xiphiplastron. Grey areas represent areas of missing bone that have been reconstructed. Scale bar $=50 \mathrm{~mm}$ 


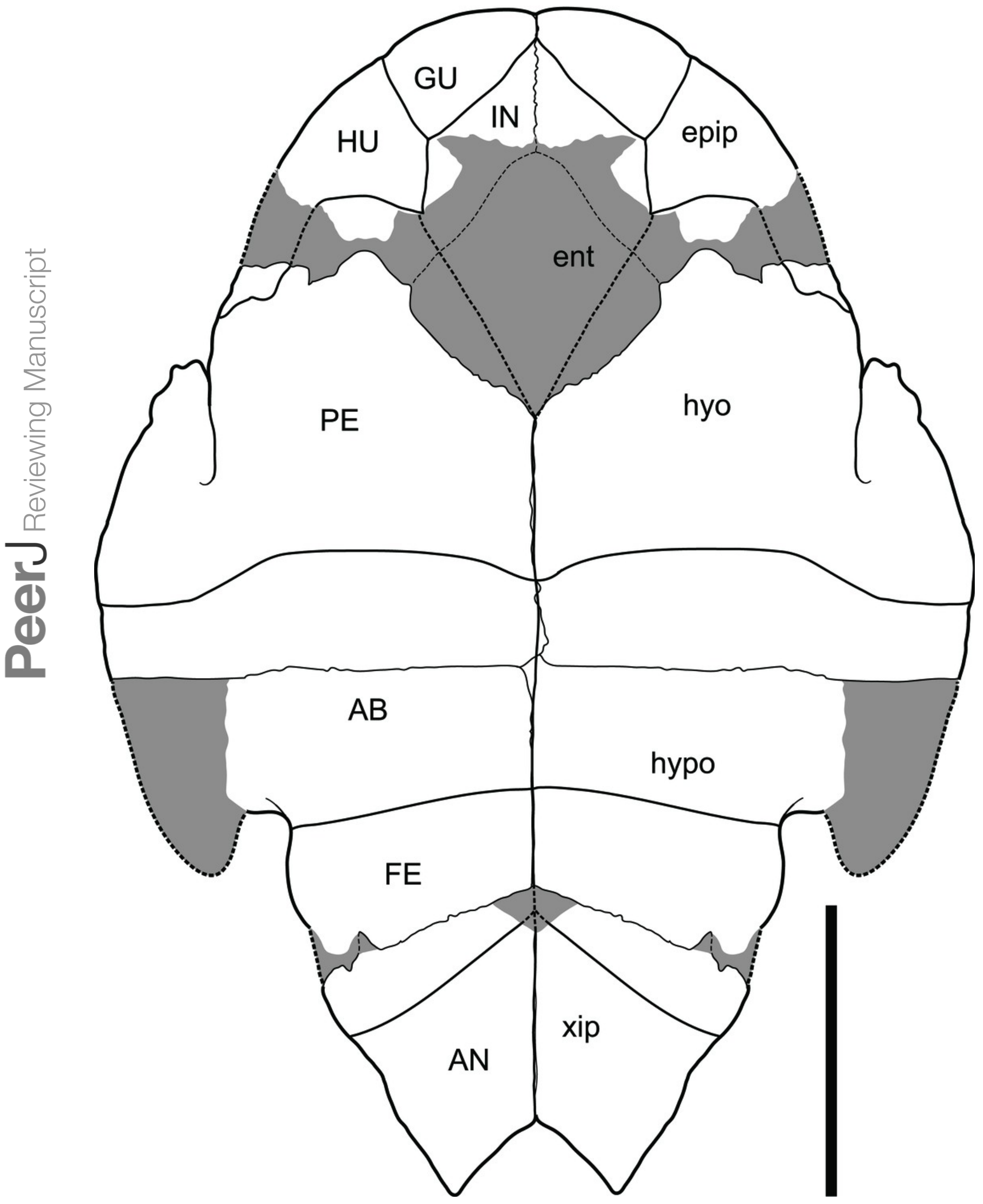




\section{Figure 6}

Figure 6. Chelodina (Chelodina) murrayi sp. nov., left hyoplastron, NTM P5369.

A , dorsal view; B, ventral view; C, anterior view; D, lateral view; E, interpretive drawing of A; $\mathbf{F}$, interpretive drawing of $\mathbf{B} ; \mathbf{G}$, interpretive drawing of $\mathbf{C} ; \mathbf{H}$, interpretive drawing of $\mathbf{D}$. Abbreviations: $\mathrm{AB}$, abdominal scute; abs, anterior bridge strut; $\mathrm{HU}$, humeral scute; PE, pectoral scute; ssca, sutural surface for articulation with the carapace; ssen, sutural surface of the entoplastron; ssep, sutural surface of the epiplastron; sshy, sutural surface of the hypoplastron; sys, symphyseal surface. Scale bar $=20 \mathrm{~mm}$. 


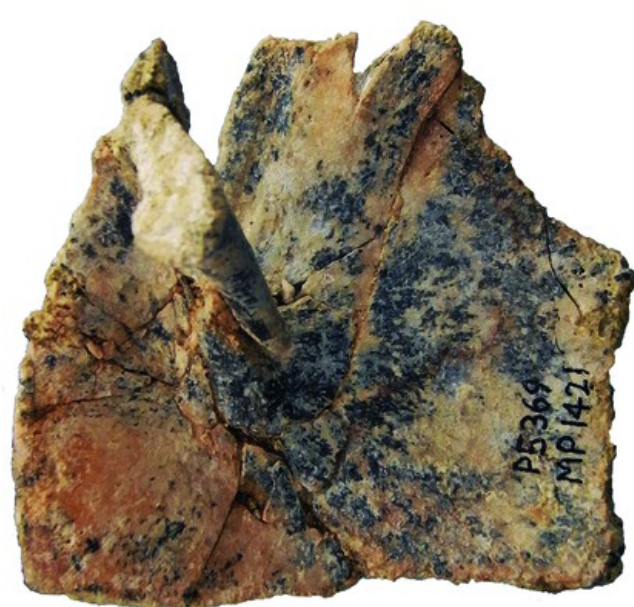

A

B
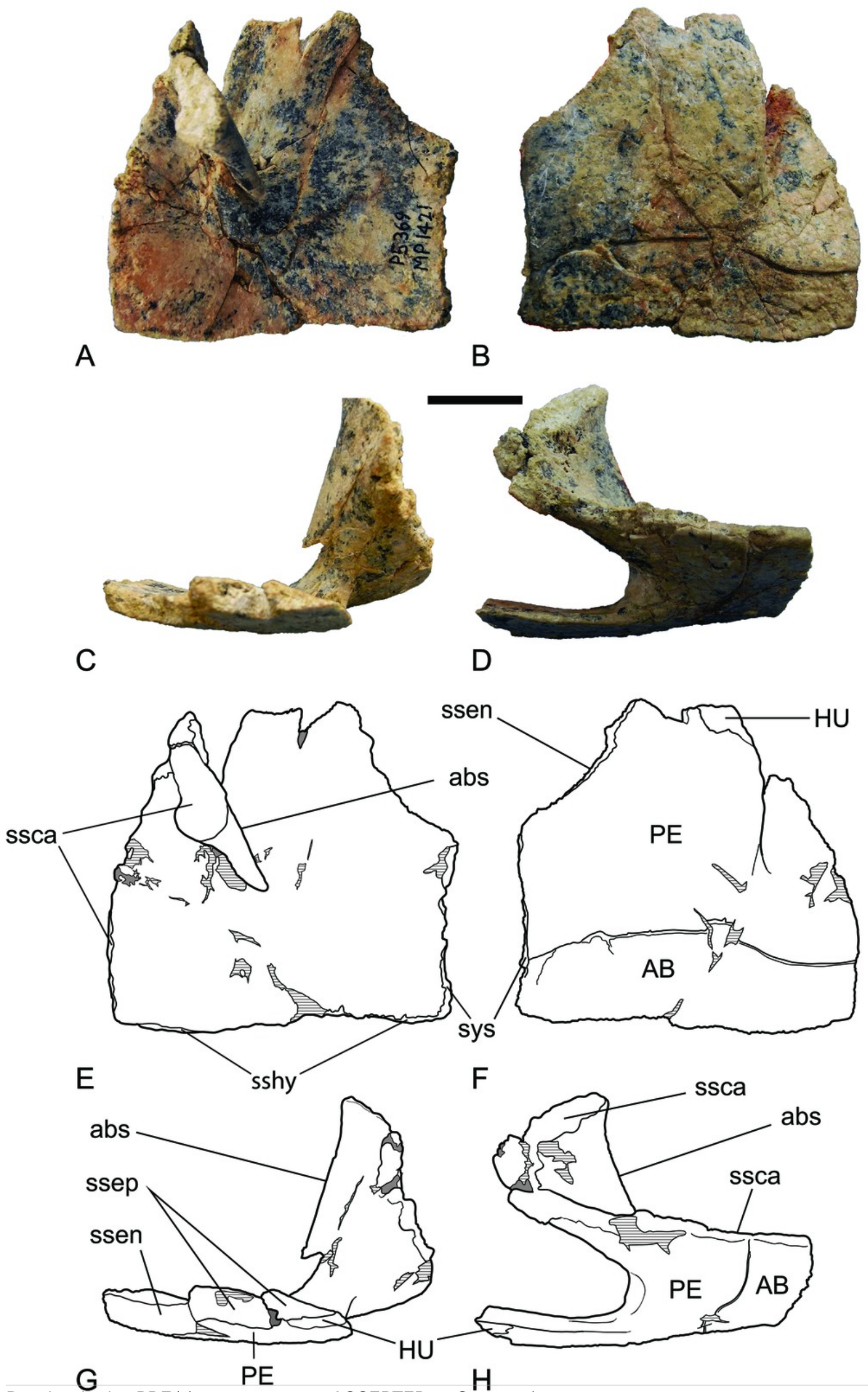

PeerJ reviewing PDF | (v2013:06:594:2:0:ACCEPTED 12 Sep 2013) 


\section{Figure 7}

Figure 7. Anterior bridge struts of various chelodinines in oblique, anterior-ventral-lateral view.

Top row: whole specimens with area of enlargement indicated by a box. Bottow row:

enlargement of anterior bridge strut area. A, Emydura sp., NTM unregistered comparative collection; B, Chelodina (Chelodina) longicollis; C, Chelodina (Chelodina) murrayi. Dotted line indicates likely extent of foramen for the axillary duct of Rathke's gland. Note that sediment partly infills this notch. Abbreviations: da, line of dermal attachment; rgf, foramen for the axillary duct of Rathke's gland.
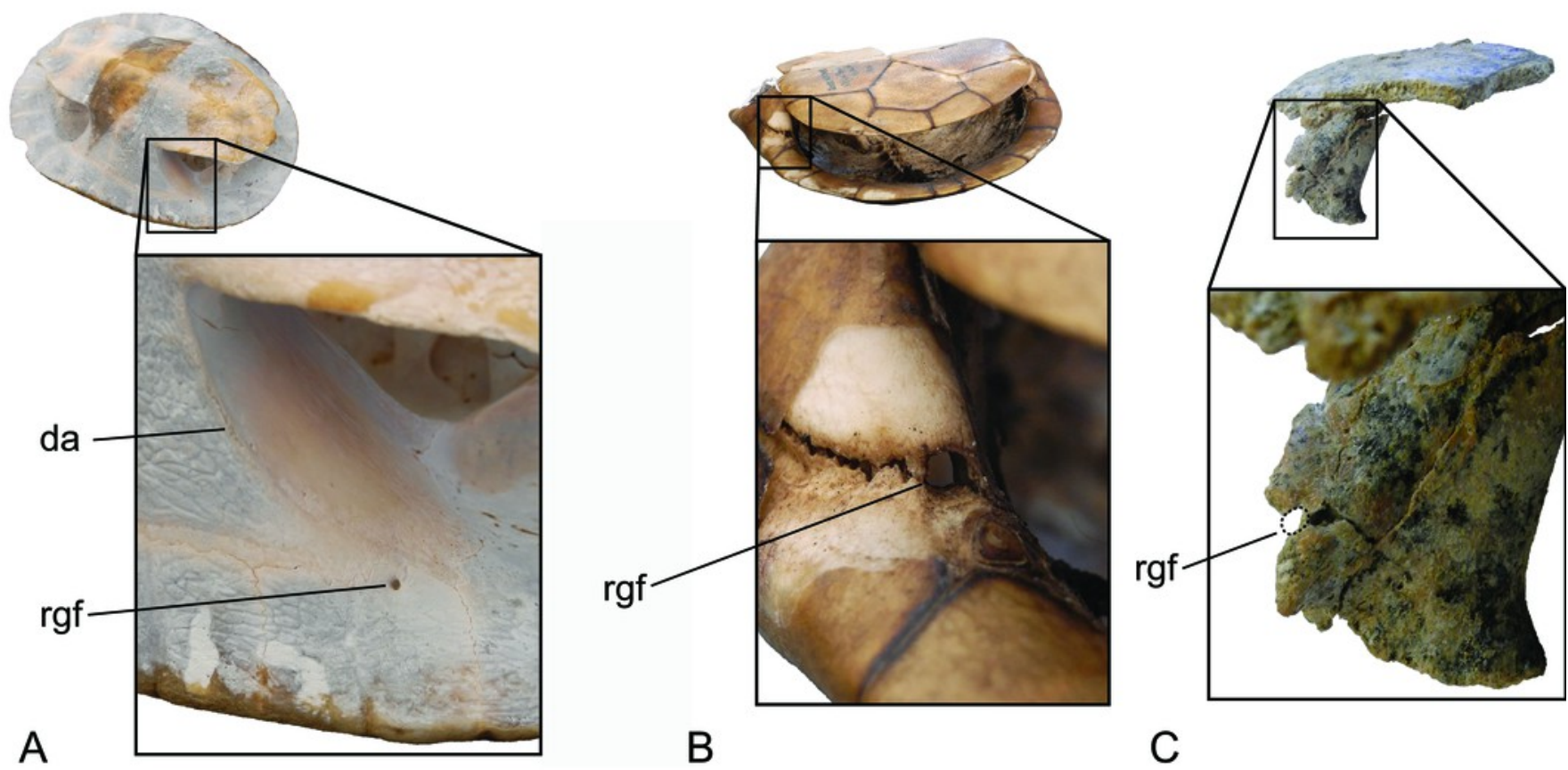


\section{Figure 8}

Figure 8. Chelodina (Chelodina) murrayi sp. nov., left hypoplastron, NTM P5375.

A , dorsal (internal) view; B, ventral (external) view; C, Interpretive drawing of A; D, Interpretive drawing of $\mathrm{B}$. Abbreviations: $\mathrm{AB}$, abdominal scute; $\mathrm{b}$, bridge; $\mathrm{FE}$, femoral scute; ssh, sutural surface for the hyoplastron; ssx, sutural surface for the xiphiplastron; sys, symphyseal surface. Hatched areas represent broken bone surfaces. Scale bar $=20 \mathrm{~mm}$.
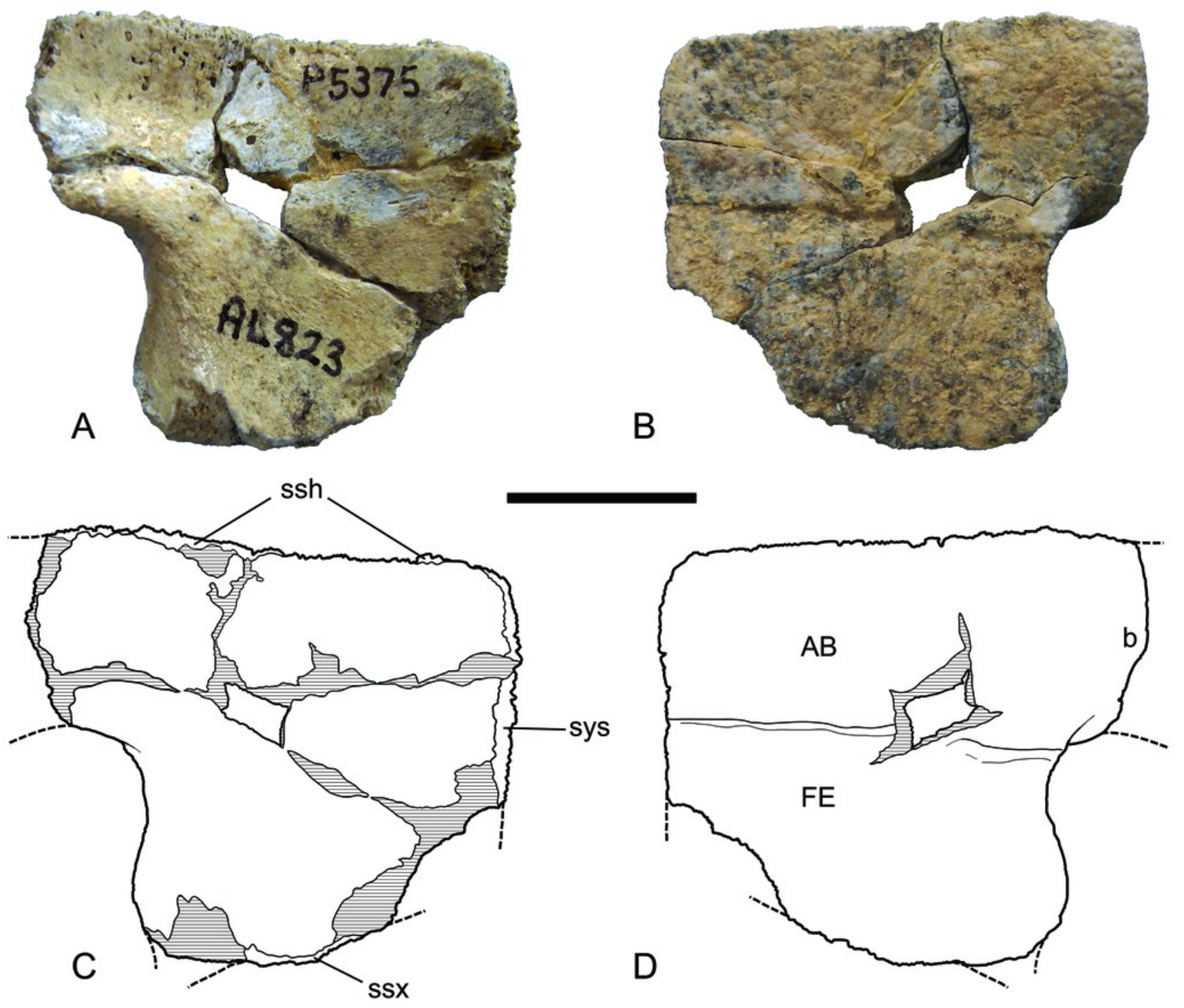


\section{Figure 9}

Figure 9. Chelodina (Chelodina) murrayi sp. nov., left hypoplastron, NTM P9810.

A , dorsal (internal) view; B, ventral (external) view; C, Interpretive drawing of A; D, Interpretive drawing of $\mathrm{B}$. Abbreviations: $\mathrm{AB}$, abdominal scute; $\mathrm{b}$, bridge; $\mathrm{FE}$, femoral scute; ssh, sutural surface for the hyoplastron; ssx, sutural surface for the xiphiplastron; sys, medial symphyseal surface. Hatched areas represent broken bone surfaces, grey areas represent patches of adherent matrix. Scale bar $=20 \mathrm{~mm}$.

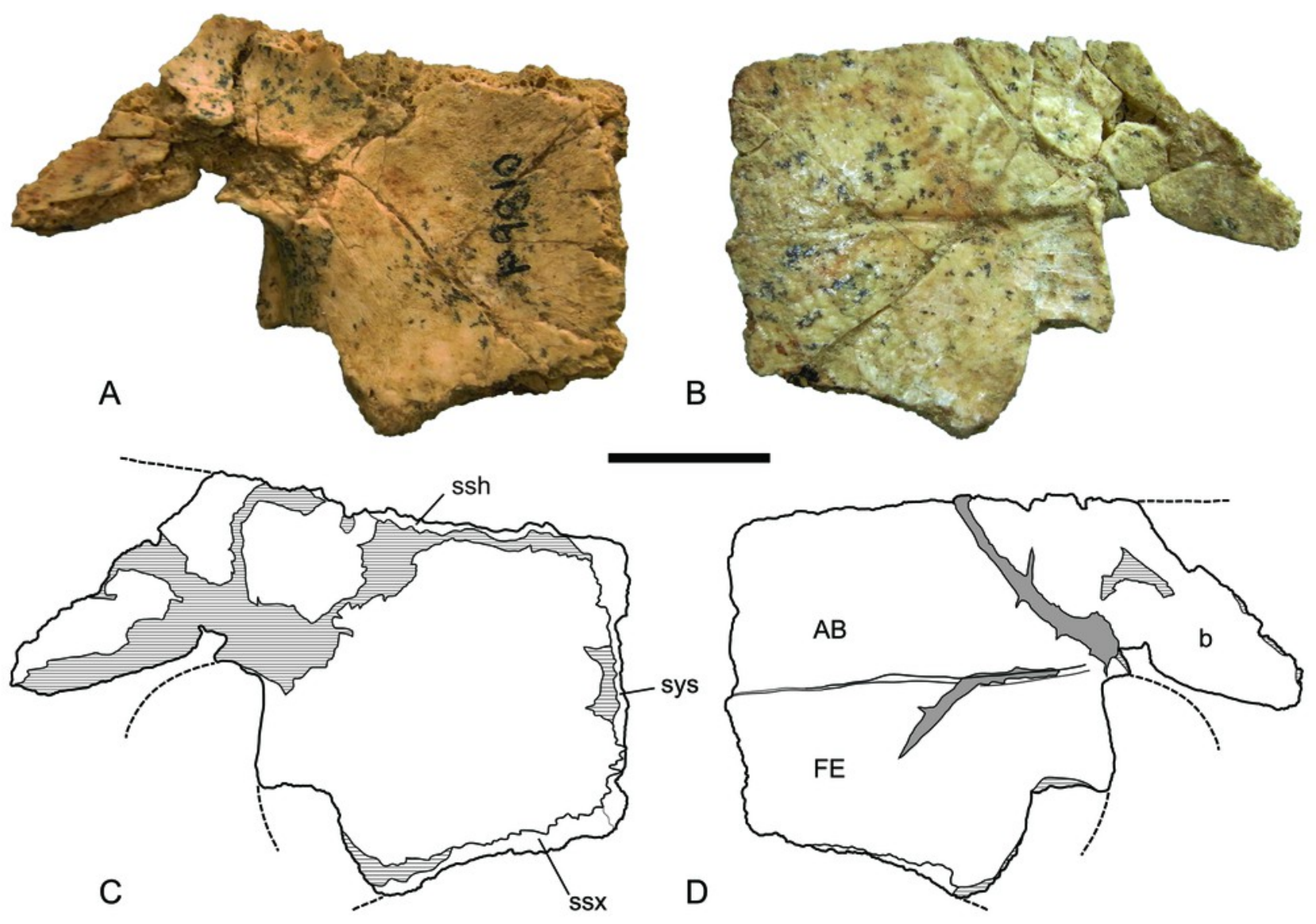




\section{Figure 10}

Figure 10. Chelodina (Chelodina) murrayi sp. nov., right xiphiplastron, NTM P5374.

$\mathbf{A}$, ventral view; $\mathbf{B}$, dorsal view; $\mathbf{C}$, interpretive drawing of $\mathbf{A} ; \mathbf{D}$, interpretive drawing of $\mathbf{B} ; \mathbf{E}$, reconstruction of articulated xiphiplastron pair in dorsal view. Abbreviations: AN, anal scute; FE, femoral scute; sshy, sutural surface for hypoplastron; ssi, sutural surface for ischium; ssp, sutural surface for pubis; sys, symphyseal surface; tm, tooth mark. Hatched areas represent broken bone surfaces, grey areas represent areas of adherent matrix. Scale bar = $20 \mathrm{~mm}$ 


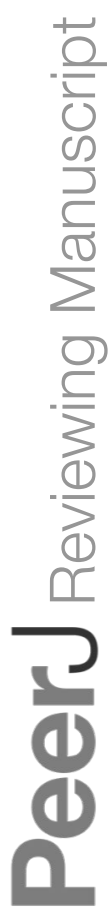
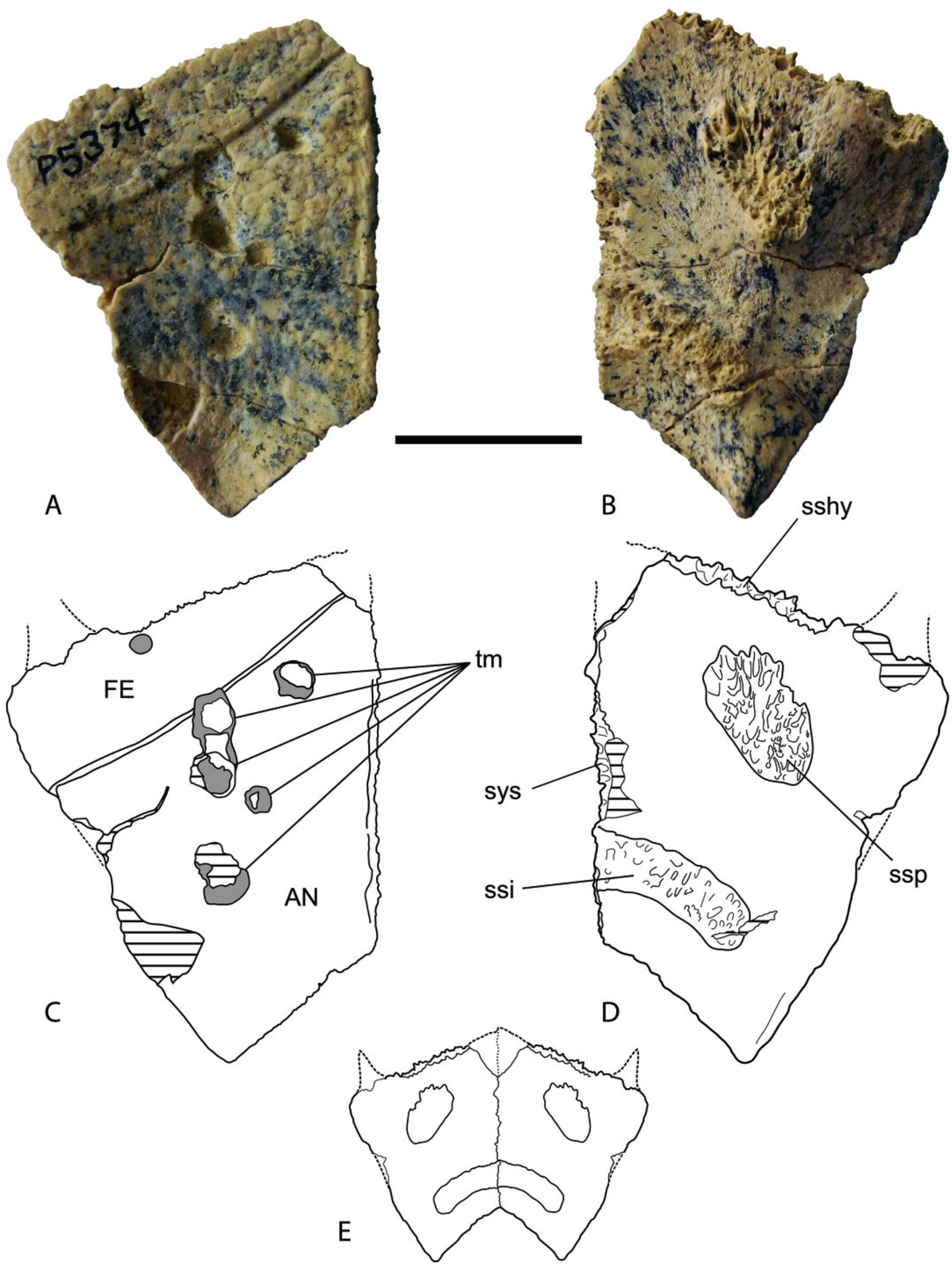


\section{Table 1 (on next page)}

Measurements of selected elements of Chelodina (Chelodina) murrayi n. sp..

$\mathrm{ML}=$ midline length $\mathrm{AW}=$ anterior width, $\mathrm{PW}=$ posterior width, $\mathrm{MS}=$ length midline

symphysis, $\mathrm{HpS}=$ length of suture with hypoplastron, $\mathrm{HS}=$ length of suture with hyoplastron, $\mathrm{XS}=$ length of suture with xiphiplastron, MW = marginal width . 


\begin{tabular}{|c|c|c|c|c|c|c|c|c|c|}
\hline Element & NTM & $\begin{array}{l}\mathrm{ML} \\
(\mathrm{mm})\end{array}$ & $\begin{array}{l}A W \\
(\mathrm{~mm})\end{array}$ & $\begin{array}{l}\text { PW } \\
(\mathrm{mm})\end{array}$ & $\begin{array}{l}\mathrm{MS} \\
(\mathrm{mm})\end{array}$ & $\begin{array}{l}\mathrm{HpS} \\
(\mathrm{mm})\end{array}$ & $\begin{array}{l}\mathrm{HS} \\
(\mathrm{mm})\end{array}$ & $\begin{array}{l}X S \\
(\mathrm{~mm})\end{array}$ & $\begin{array}{l}\mathrm{MW} \\
(\mathrm{mm})\end{array}$ \\
\hline Nuchal & P5370 & 57.3 & 32.0 & 52.0 & - & - & - & - & - \\
\hline $\begin{array}{l}\text { Epiplastro } \\
\mathrm{n}\end{array}$ & P5364 & - & - & - & (23.9) & - & & & \\
\hline $\begin{array}{l}\text { Hyoplastro } \\
n\end{array}$ & P5369 & - & - & - & 41.3 & 71.9 & - & - & - \\
\hline \multirow[t]{2}{*}{$\begin{array}{l}\text { Hypoplastr } \\
\text { on }\end{array}$} & P9810 & - & - & - & 33.6 & & $(45.6)$ & (27.7) & \\
\hline & P5375 & - & - & - & (26.1) & - & (49.8) & - & - \\
\hline $\begin{array}{l}\text { Xiphiplastr } \\
\text { on }\end{array}$ & P5374 & - & - & - & (34.4) & (34.3) & & & \\
\hline $\begin{array}{l}\text { Peripheral } \\
2\end{array}$ & P5337 & - & - & - & - & - & - & - & 22.0 \\
\hline $\begin{array}{l}\text { Peripheral } \\
10\end{array}$ & P5373 & - & - & - & - & - & - & - & 24.0 \\
\hline
\end{tabular}




\section{Table 2 (on next page)}

Ratio of intergular scute length to length of the shared seam between pectoral scutes in various chelodinines. 


\begin{tabular}{|c|c|c|}
\hline Species & $\begin{array}{l}\text { Rati } \\
\text { o }\end{array}$ & Source \\
\hline Pseudemydura umbrina & 1.35 & Burbidge et al. 1974, fig. 1 \\
\hline Emydura sp. & 0.55 & NTM (MCA unregistered) \\
\hline Chelodina (Macrodiremys) collei & 1.43 & Burbidge et al. 1974, fig. 2 \\
\hline Chelodina (Macrochelodina) rugosa & 1.53 & NTM R24814 \\
\hline Chelodina (Macrochelodina) rugosa & 1.40 & Thomson et al. 2000 , fig. $6 b$ \\
\hline $\begin{array}{l}\text { Chelodina (Macrochelodina) } \\
\text { burrungandjii }\end{array}$ & 1.23 & NTM R35010 \\
\hline $\begin{array}{l}\text { Chelodina (Macrochelodina) } \\
\text { burrungandjii }\end{array}$ & 1.14 & Thomson et al. 2000 , fig. $6 a$ \\
\hline Chelodina (Macrochelodina) parkeri & 1.18 & $\begin{array}{l}\text { Rhodin \& Mittermeier 1976, fig. } \\
15\end{array}$ \\
\hline Chelodina (Chelodina) Iongicollis & 3.25 & NTM R27168 \\
\hline Chelodina (Chelodina) canni & 5.35 & NTM R16325 \\
\hline $\begin{array}{l}\text { Chelodina (Chelodina) } \\
\text { novaeguineae }\end{array}$ & 3.20 & $\begin{array}{l}\text { McCord \& Thompson 2002, fig. } \\
\text { 3f }\end{array}$ \\
\hline $\begin{array}{l}\text { Chelodina (Chelodina) } \\
\text { novaeguineae }\end{array}$ & 2.79 & Rhodin 1994a, fig. 7 \\
\hline Chelodina (Chelodina) pritchardi & 3.13 & Rhodin 1994a, fig. 1 \\
\hline Chelodina (Chelodina) reimanni & 2.37 & $\begin{array}{l}\text { Philippen \& Grossmann 1990, } \\
\text { fig. } 2\end{array}$ \\
\hline
\end{tabular}

